\title{
Would Stricter Capital Requirements Raise the Cost of Capital? Bank Capital Regulation and the Low Risk Anomaly ${ }^{1}$
}

\author{
Malcolm Baker \\ Harvard Business School and NBER \\ Jeffrey Wurgler \\ NYU Stern School of Business and NBER
}

March 15, 2013

\begin{abstract}
Capital requirements for banks must balance a number of factors, including any effects on the cost of capital and in turn the rates available to borrowers. Standard theory predicts that, in perfect and efficient capital markets, reducing banks' leverage would reduce the risk and cost of their equity but leave the overall weighted average cost of capital unchanged. We test these two predictions empirically. We confirm that the equity of better-capitalized banks has both lower systematic risk (beta) and lower idiosyncratic risk. However, over the last 40 years in the United States, lower risk banks have higher stock returns on a risk-adjusted or even a raw basis, a pattern consistent with a stock market anomaly previously documented in other samples. A simple calibration using historical data suggests that a ten percentage-point increase in Tier 1 capital to risk-weighted assets would have increased the weighted average cost of capital by between 60 and 90 basis points per year. In competitive lending markets, a change of this magnitude would have doubled or tripled spreads, because bank asset betas implied an average risk premium of only 40 basis points above Treasury yields over that same period.
\end{abstract}

\footnotetext{
${ }^{1}$ For helpful comments we thank Yakov Amihud, Jon Bernstein, Robin Greenwood, Alec Guzov, Victoria Ivashina, Thomas McGuire, Hamid Mehran, Antony Saunders, David Scharfstein, Amit Seru, Adi Sunderam, Jeremy Stein, Robert Turley, seminar participants at Harvard Business School and NYU Stern School of Business, and especially Sam Hanson. We thank Alex Guzov and Robert Turley for excellent research assistance. In addition to their academic affiliations, Baker and Wurgler serve as consultants to Acadian Asset Management. Baker gratefully acknowledges financial support from the Division of Research of the Harvard Business School.
} 


\section{Introduction}

The instability of financial institutions apparent in the financial crisis of 2008 has led to calls for increased capital requirements. The issue is multidimensional, involving agency problems in banks, asymmetric information, international coordination, bank governance, tax benefits of debt, government subsidies, systemic risks, shadow banking, and so on. But a central concern is whether capital requirements affect banks' overall cost of capital, and therefore lending rates and economic activity. ${ }^{2}$

Bankers often resist increased capital requirements on the argument that equity is more expensive than debt, so more of it raises the overall cost of capital. A former managing director of JP Morgan and policy analyst writes, "the first-order effect of increasing the ratio of common equity to total assets for banks from $5 \%$ to $30 \%$ would clearly be very high. Assume that the annual cost of bank equity is 5 percentage points higher than the after-tax cost of bank deposits and debt. ...” (Elliott (2013)). The CEO of Deutsche Bank argues that heightened capital requirements “would restrict [banks'] ability to provide loans to the rest of the economy. This reduces growth and has negative effects for all” (Admati and Hellwig (2013), p. 5).

Many economists, on the other hand, view the weighted average cost of capital as more or less invariant to capital structure. They consider the argument above a fallacy. Admati, DeMarzo, Hellwig, and Pfleiderer (2011) sum up the textbook Modigliani-Miller logic: “[B]ecause the increase in capital provides downside protection that reduces shareholders' risk, shareholders will require a lower expected return to invest in a better capitalized bank" (p. 16). In an efficient and integrated capital market, absent taxes and other distortions, the reduced cost

\footnotetext{
${ }^{2}$ See Cummins, Hassett, and Hubbard (1994), Philippon (2009), Gilchrist and Zakrajsek (2012) and citations therein for evidence on the effect of costs of capital on business investment. Broader studies of the real effects of bank capital requirements include Van den Heuvel (2008), Macroeconomic Assessment Group of the Basel Committee on Banking Supervision (2010), Basel Committee on Banking Supervision (2010), Elliott (2009, 2010), and Santos and Elliott (2012).
} 
of equity offsets its increased weight in the capital structure and leaves the overall cost of capital unchanged. Admati and Hellwig (2013) suggest raising the minimum equity to assets ratio to between $20 \%$ and $30 \%$ from its current single digits. But given that real capital markets contain frictions and inefficiencies that challenge almost all of the Modigliani-Miller assumptions, the validity of the textbook conservation of risk argument is not so clear. ${ }^{3}$

In this paper, we attempt to determine how leverage affects the risk and cost of bank equity and the overall cost of capital in practice. We are particularly motivated by the potential interaction of capital requirements and the "low risk anomaly" within the stock market. While stocks have on average earned higher returns than less risky asset classes like corporate bonds, which in turn have earned higher returns than Treasury bonds, the risk-return relationship within the stock market has historically been flat if not inverted. Haugen and Heins (1975), Fama and French (1992), Baker, Bradley, and Wurgler (2011), and Baker, Bradley, and Taliaferro (2013) find a flat or negative relationship between a stock's systematic risk, as measured by its stock market beta, and its subsequent returns. Ang, Hodrick, Ying, and Zhang $(2006,2009)$ find a negative relationship between idiosyncratic risk and returns in the U.S. and many international stock markets.

These studies suggest that there is a low risk anomaly on average within the stock market. The relevant question for bank capital regulation is whether this holds within banks specifically. Does the cost of equity fall with capital requirements as the Modigliani-Miller logic predicts? Or does it not fall by enough, or actually increase, as bankers and the low risk anomaly would imply? Indeed, the low risk anomaly might not be present in banks at all. Relative to

\footnotetext{
${ }^{3}$ Admati et al., for instance, cite seven theoretical papers in the relevant section but only one empirical paper, Kashyap, Stein, and Hanson (2010), which does not estimate the cost of equity directly.
} 
nonfinancial firms, their financial structure and risk are tracked in considerably greater detail by regulators and investors.

Our empirical evaluation proceeds in two steps. First, we relate bank equity betas estimated from CRSP to leverage ratios from quarterly reports. Second, we relate realized returns on equity to bank equity betas. We also replace beta with idiosyncratic risk. The two steps together then allow us to calibrate the effect of increased capital requirements on the cost of equity and, under certain assumptions, the overall cost of capital.

We confirm that bank equity risk is sharply increasing in leverage. Our work here complements and extends that of Kashyap, Stein, and Hanson (2010). When capital is measured by the standard Tier 1 capital to risk-weighted assets ratio, the portfolio beta of the leastcapitalized banks is 0.93 while the portfolio beta of the most-capitalized banks is 0.50 . Higher capital ratios also predict lower idiosyncratic risk. Even this relatively large difference in beta is likely attenuated by two factors. Banks with riskier assets may choose to have larger capital cushions. This endogenous selection tends to reduce the slope between capital ratios and beta. Indeed, within the largest banks, where the asset mix is more varied, including investment banking, asset management, and other operations, the difference is smaller and less robust. Also, to the extent that debt is risky, some of the asset risk is borne by debt and not equity for the most leveraged banks. This type of risk sharing between debt and equity also flattens the empirical relationship. Overall, the first step of the textbook argument holds as expected.

Does a reduction in beta translate to a reduction in the cost of equity? The answer contained in the most recent 40 years of CRSP stock returns is no. The low risk anomaly is actually a bit stronger within banks than within all publicly traded firms. High-beta banks returned less than low-beta banks, even on a raw basis, in a period of mostly rising equity 
markets. Value-weighted returns are on average 16 basis points per month higher for a portfolio of the lowest three beta deciles than for a portfolio of the highest three beta deciles. The spread between low and high idiosyncratic risk portfolios is 6 basis points per month. These effects do not appear to be mediated by capitalization. Controlling for a size factor increases the riskadjusted differences, especially for idiosyncratic risk portfolios. More simply, beta is positively correlated with capitalization while idiosyncratic risk is negatively correlated, yet both risk types are negatively related to average returns.

We focus on the last 40 years of data because earlier stock returns data includes only a small number of banks, rendering portfolio returns much less diversified and conclusions more tenuous. Nonetheless, results using the last 80 years of data are at least as strong. The bottom line is that high-risk U.S. banks, like high-risk nonfinancial firms in the U.S. and other developed markets, have delivered equal or lower returns to shareholders the low-risk U.S. banks.

To understand the economic significance of the results, we focus on the beta anomaly and estimate how the overall cost of capital for a bank would have changed over this period given a hypothetical ten percentage-point increase in Tier 1 capital to risk-weighted assets, the experiment considered in Kashyap et al. (2010). A benchmark estimate of the basic weighted average cost of capital for a typical bank implied by the Capital Asset Pricing Model over the same 40-year period is 40 basis points per year above the risk-free rate. By reducing equity betas, banks with a full ten percentage point increase in Tier 1 capital would have added between 60 and 90 basis points to this spread—more than doubling the weighted average cost of capital over the risk-free rate. In a competitive lending market this would have translated to a similar increase in average bank lending rates. To the extent that the shadow banking system was not similarly 
constrained, lending would have moved more rapidly from banks to flexible and less regulated parts of the capital market.

The critical assumption in the simple calibration is that the linear, historical relationship between risk and return would have held, as banks were required to shift their risk profile. A less important assumption is that bank debt was approximately risk-free. We also consider the sensitivity of this calibration to the assumption of risky debt, the extension of a low risk anomaly to debt as well as equity markets, and the impact of government insurance of bank debt. We conclude that as long as the debt and equity markets were not perfectly integrated—the underpinning of Modigliani-Miller logic—-the simple calibration with riskless debt remains a reasonable estimate.

In summary, our contribution is to highlight how the low risk anomaly within banks may represent an unrecognized and possibly substantial downside of heightened capital requirements. It is separate from and additive to the increase in the cost of capital and lending rates through a smaller debt tax shield. Kashyap et al. (2010) estimate the other effects of a ten percentage-point increase in capital requirements to be 25 to 45 basis points. We emphasize, however, that despite the fact that tightened capital requirements may considerably increase the cost of capital and lending rates, with adverse implications for investment and growth, they may well remain desirable when all other private and social benefits and costs are tallied up.

Section II gives some background on the low risk anomaly. Section III describes stock returns and capital adequacy data. Section IV contains the main results on the connections between beta, capital levels, and costs of equity. Section V summarizes recent regulatory trends and performs a calibration exercise. Section VI concludes. 


\section{The Low Risk Anomaly}

Over the long run, riskier asset classes have earned higher returns in U.S. markets. From 1926 to 2012, small capitalization stocks provided higher but more variable returns than large capitalization stocks, which in turn were riskier and returned more than long-term corporate bonds, and so on down the list of increasingly safer asset classes of long-term Treasury bonds, intermediate-term Treasury bonds, and Treasury bills (Ibbotson Associates (2012)).

More relevant to our study is that the historical risk-return tradeoff within the stock market is flat or inverted. The standard Sharpe-Lintner Capital Asset Pricing Model (CAPM) predicts that the expected return on a security is proportional to its systematic risk (beta). Investors are assumed to diversify away idiosyncratic risk so it does not affect their required returns. The "low risk anomaly" is the empirical pattern that stocks with higher beta, or higher idiosyncratic risk, have tended to earn lower returns.

To a greater or lesser extent, this failure of the traditional risk-return tradeoff appears in stock markets around the world. Black (1972), Black, Jensen, and Scholes (1972), Haugen and Heins (1975), and Fama and French (1992) all noted the relatively flat relationship between expected returns and beta risk. The more recent work of Ang, Hodrick, Ying, and Zhang (2006, 2009) has emphasized the magnitude and robustness of the anomaly. Ang et al. (2009) find that stocks with higher idiosyncratic risk earn statistically significantly lower returns in each of the G7 countries and across 23 developed markets. Blitz and van Vliet (2007) and Baker, Bradley, and Taliaferro (2013) confirm the low risk anomaly within developed markets and Blitz, Pang, and van Vliet (2012) extend this to emerging markets, where it appears to be growing over time. These patterns challenge not just the CAPM but also any asset-pricing framework where risk and return are positively related. 
The magnitude of the risk-return inversion is large. For example, Baker, Bradley, and Taliaferro (2013) find that a dollar invested in a low quintile beta portfolio of U.S. stocks in early 1968 grows to $\$ 70.50$ by the end of 2011 , a while dollar invested in a high beta portfolio grows to only $\$ 7.61$. In a sample of up to 30 developed equity markets over a shorter period beginning in 1989 , the comparable figures are $\$ 6.40$ and $\$ 0.99$. It is remarkable that a value-weighted portfolio of high-risk quintile stocks held for four decades did not earn the investor a positive return in nominal terms.

Several explanations for the low risk anomaly have been put forth. A variety of evidence suggests that some individual investors have an irrational preference for volatile or skewed investments, due to overconfidence, as in Cornell (2008), or lottery preferences, as in Kumar (2009), Bali, Cakici, and Whitelaw (2011) and the cumulative prospect theory of Tversky and Kahneman (1992) as modeled by Barberis and Huang (2008). Leverage-constrained investors who pursue a strategy of seeking high returns from beta risk must invest in high-beta stocks directly, leading them to be overpriced relative to a leveraged position in low-beta stocks (Black (1972) and Frazzini and Pedersen (2013)).

One question is why more sophisticated investors do not take advantage of the anomaly. Institutional fund managers may prefer high-beta assets themselves because the inflows to performing well are greater than the outflows to performing poorly (Karceski (2002)). Another reason for a high-beta preference is when managers are rewarded for beating the market, which presumably has a positive risk premium, on a non-beta-adjusted basis (Brennan (1993) and Baker et al. (2011)). More generally, short-selling constraints inhibit sophisticated investors' ability to exploit the overpricing of high-beta stocks (Hong and Sraer (2012)). 
For our purposes, the precise origin of the low risk anomaly is not critical. What matters is whether it exists among banks and, if so, is likely to persist. Given that overconfidence and lottery preferences are intrinsic human attributes; that leverage and short-sale constraints are enduring features of the trading environment; that institutional investors and their incentives are only becoming more important over time; and that the low risk anomaly apparent within allindustry samples appears in long U.S. and international samples—it seems reasonable to maintain that any low risk anomaly present within banks would persist.

The low risk anomaly has parallel implications for investors and CFOs. Low risk stocks, at least with the benefit of high returns in hindsight, have been priced cheaply on average. So, raising equity capital for these firms has been comparatively expensive. High risk stocks, by contrast, have been expensive, and the cost of raising equity for these firms has been comparatively low. One might well ask why operating firms have not increased their leverage ratios more to take advantage of the low risk anomaly. It is hard to square the low leverage ratios of nonfinancial firms simply with a tradeoff between the tax benefits of interest and the costs of financial distress, much less an extra benefit of debt arising from the mispricing of low risk stocks. ${ }^{4}$ It is worth noting that many of these low leverage firms—-think of the stereotypical profitable technology firm—start with a high asset beta or overall asset risk. For our purposes, it is simple enough to say that there is no low leverage puzzle within banks.

Banks in particular tend to rely largely on debt to finance their lending operations and generally start with a very low asset beta. This means that without significant leverage their equity might in many cases resemble investment grade debt in terms of risk. This puts another lens on the low risk anomaly, and suggests a possible remedy to the mispricing that could arise

\footnotetext{
${ }^{4}$ See Graham (2000) on the low leverage puzzle. The low risk anomaly suggests another source of profits from leveraged buyouts, if the equity of a low-leverage firm is made more valuable by increasing its risk.
} 
from significantly heightened capital requirements. It is perhaps that the mere categorization of a security as equity leads investors to demand a return that resembles the return on other stocks, regardless of its particular risk properties. Coval, Jurek, and Stafford (2009) argue that such investor behavior influenced the pricing of highly rated collateralized debt obligations. This suggests a marketing effort, albeit perhaps an unrealistic one, would be required to help investors differentiate low leverage bank equity from similarly labeled equity in industrial firms.

But before making any policy prescriptions, we ask whether the combination of an exogenous increase in capital requirements and the low risk anomaly would increase the overall cost of capital for banks. The first step is to ask whether heightened capital requirements would reduce equity risk for banks. The second is to ask whether the low risk anomaly holds within banks such that the increase in equity would raise the cost of capital. In general, we focus on beta risk, where the Modigliani-Miller logic best applies, but we also explore idiosyncratic risk.

\section{Data}

\section{A. Banks, Betas, and Returns}

Estimating the relationship between expected equity returns—alternatively, the required return on equity or the cost of equity — and beta requires both a long time series of returns and a large number of banks to provide breadth in beta. Our main sample for the returns analysis includes almost 4,000 publicly traded banks or bank holding companies that make an appearance in over 40 years of returns data, for a total of more than a quarter of a million bank-months of returns.

We gather bank stock prices and returns data from January 1931 through December 2011 from the Center for Research in Securities Prices (CRSP) database. We focus our attention on 
the second half of the sample, the most recent 40.5 years starting in July 1971 . We save the full sample as a robustness check, because there are relatively few publicly traded banks in the early CRSP years, rendering the beta portfolios undiversified and highly volatile. ${ }^{5}$ We identify banks using the set of four-digit SIC codes suggested in Fama and French (1997) plus the three-digit SIC code corresponding to bank holding companies. ${ }^{6}$ The primary sample includes bank-months for which we can compute a valid beta, with at least 24 monthly holding period return (CRSP: RET) observations, a valid market capitalization, with a nonmissing price (PRC) and shares outstanding (SHROUT) observation, and at least one holding period return following a valid beta. Due to the return requirements, the bank-months we follow run from February 1970 through December 2011.

The primary sample of banks is broken down by decade and SIC in Table 1. Holding companies are the most numerous group, followed by savings institutions, commercial banks, state banks in the Federal Reserve System, national commercial banks, S\&Ls, and national banks in the Federal Reserve System. A total of 3,952 banks make an appearance over the course of our CRSP sample.

Summary statistics for this sample are in Table 2. The bank-month observations are divided by pre-ranking risk measures. Pre-ranking beta is computed for each bank-month by regressing a minimum of 24 months and a maximum of 60 months of trailing holding period returns in excess of the riskless rate on the corresponding CRSP U.S. value-weighted market holding period returns (CRSP: VWRETD, also in excess of the riskless rate, and provided by

\footnotetext{
${ }^{5}$ After July 1971, there are at least 70 firms in the sample. Prior to July 1971, there are between five and 69 banks, with an overall average of 22.

${ }^{6}$ We exclude a small number of firms included in Fama and French's definition of banks: those with SIC classifications as Federal Reserve Banks, Foreign Banks, Functions Related to Deposit Banking, Nondepository Credit Institutions, Federal Credit Agencies, or FNMA. Including these firms has no effect on our results.
} 
Ken French). We also take the root mean squared error from these regressions as our measure of idiosyncratic risk. This pre-ranking beta is what we will use to rank banks when tracking subsequent returns. We will consider forward (realized) betas and idiosyncratic risk as well when correlating beta and capital ratios.

It is worth noting at the outset that bank betas on an equal weighted basis are relatively low. The overall median is only 0.67 . There is also ample spread on pre-ranking equity beta among our bank sample. The mean pre-ranking beta among the bottom three deciles is 0.18 and the mean among the top three deciles is 1.37. More importantly, we will see that this pre-ranking spread leads to differences in realized portfolio betas of approximately 0.6. Another important pattern from Table 2 is the correlations between risk measures and capitalization. Beta is higher for large banks, while idiosyncratic risk is lower. As we shall also see, the risk measures imply similar conclusions for leverage and returns, suggesting that the results are not being mediated by capitalization.

In total, this broad sample contains up to 272,031 bank-months for our beta and returns analysis. We also use three control variables common in the analysis of the cross-section of stock returns; e.g. Fama and French (1992) and Jegadeesh and Titman (1993). As suggested above, higher-beta banks tend to be larger market capitalization. This is the opposite of the negative correlation between beta and market capitalization among nonfinancial firms. Bank holding companies may have units such as investment banking where profits are more correlated with the overall stock market. Also, smaller firms, with less geographic and product diversification, may choose less risky operations with endogenously higher capital. To the extent that the endogenous link is through idiosyncratic risks, not beta, this is a useful form of identification for us. 
We also compute book-to-market equity ratios. Book equity data are available for a subset of stocks from Compustat, sourced from Moody’s. We follow the definition of book equity from Ken French’s data library. Within each beta group there is skewness in book-tomarket; it will come as no surprise that some banks have seen the market value of their assets deteriorate faster than they were marked down. The median ratio across beta groups is an identical 0.76. Another control variable is return momentum, defined as usual as the total stock return over the prior twelve months excluding the most recent one.

Figure 1 shows the time series of the average betas in each quantile. In an average year there is a spread of around 1.0 between the average beta in the top three deciles and the bottom three deciles. The average CRSP market return over the riskless rate is $6 \%$ and the standard deviation is $18 \%$ over our sample period, suggesting meaningful dispersion in CAPM-based expected equity returns and very wide dispersion in market-driven realized returns. There is a jump in the number of smaller banks in 1973, when Nasdaq-listed firms first appear in the CRSP database. This influx of typically lower-beta banks brings down average betas significantly in the early years, to a range and spread that has remained somewhat stable since the mid-1970s.

\section{B. Bank Capital}

We are able to gather capitalization data for a subset of the CRSP sample from the quarterly call reports data in the WRDS Bank Regulatory database. We use the CRSP PERMCO to bank RSSID ID link table available from March 1996 through December 2010 that is provided by WRDS; we start at 1996 with the introduction of granular capital data. In cases of multiple RSSIDs per PERMCO, we aggregate RCFD data items across RSSIDs. An alternative approach that yields similar results (unreported) is to use the quarterly Compustat data items on capital 
adequacy for banks. Our overall coverage is slightly better using the aggregation of call reports. Finally, we merge CRSP PERMCOs to PERMNOs.

We consider five common capital ratios to determine which measure of equity best lines up with equity beta. The ratio of total equity capital (RCFD3210) divided by average total assets (RCFD3368) is the simple shareholder equity ratio. Tier 1 capital (RCFD8274, which is first available in March 1996) to average total assets is called the leverage ratio. Total risk-based capital (RCFD3792) to assets puts the sum of Tier 1 and Tier 2 capital in the numerator. Tier 1 capital to total risk-weighted assets (RCFDa223) is the widely followed Tier 1 capital ratio. Total risk-based capital to total risk-weighted assets is called the total capital ratio. Scaling by risk-weighted assets is an effort to address the possibility that asset beta may differ somewhat across our sample.

We distribute these quarterly capital data across relevant months to yield an intersection of 74,105 bank-months with the basic returns data set. Table 3, Panel A, shows the distribution of these measures of bank capital. The sample is divided each month into ten deciles of capital adequacy. We report the median and market-capitalization weighted mean ratio within each decile. In this somewhat heterogeneous sample of banking institutions, the average capital ratios in the highest decile are typically around twice those of the lowest decile. The highest spread appears in the ratio Tier 1 capital to risk-weighted assets, which over this period was widely regarded as the most important measure of capital by market participants. 


\section{Analysis}

\section{A. Predictions: Capital Adequacy, Beta, and Returns}

In efficient capital markets, higher capital ratios will be associated with lower equity betas and lower equity returns, all else equal. Capital structure is endogenous, however, so we cannot use the cross-sectional relationship between capital ratios and beta to measure the causal effect of an increase in capital requirements. These effects tend to attenuate the relationship between capital ratios and equity beta. So, if there is a meaningful difference between endogenously selected capital ratios and empirical equity betas, we can be comfortable that exogenous effects would be at least as large.

Figure 2 shows some basic predictions for how leverage affects equity betas. Writing the definition of asset beta as a weighted average of equity and debt betas, with $e$ being the ratio of equity to total assets and the inverse of $e$ leverage, and rearranging, yields

$\beta_{e}=\frac{1}{e} \beta_{a}-\left(\frac{1}{e}-1\right) \beta_{d}$.

With approximately riskless debt, the last term drops out and the relationship between equity beta and leverage is linear with a slope of asset beta, as shown with the solid line in Figure $2{ }^{7}$ The effect of risky debt is apparent at high leverage, where debt's beta rises and causes equity's beta to rise less than linearly, as indicated by the dashed line on the right-hand side of Figure 2 .

When banks differ in their asset betas, endogenous leverage choice due to financial distress costs leads to an additional effect that flattens the predicted relationship between equity beta and leverage. Banks with high asset betas, and therefore high equity betas for any given leverage, will tend to choose lower leverage. Similarly, and reinforcing the risky debt effect,

\footnotetext{
${ }^{7}$ It is worth a reminder that the weighted average of equity and debt betas equals asset beta by identity, in the same way that the beta of any portfolio is the weighted sum of the betas in the portfolio. The CAPM is not required for its validity. Also note that a debt tax shield do not alter this formula as long as the bank continuously rebalances its debt to maintain a constant debt to value ratio; the tax shield asset is as risky as the operating assets.
} 
banks with low asset betas, and thus low equity betas for any given leverage, may choose higher leverage. To summarize, the dashed line in Figure 2 is what we would expect from this realworld combination of risky debt and endogenous capital structure choice. The coefficient in a regression of equity betas on inverse capital ratios is likely to be somewhat lower than the asset beta, particularly for extreme levels of leverage.

This discussion also suggests why we want to go from capital adequacy to returns in two steps—-from capital to beta, and from beta to returns—as opposed to directly from capital to returns. As explained above, capital is endogenous in a way that may attenuate the results we are looking for: High capital firms tend to have riskier assets to start with. Critically, however, this endogenous selection of capital will be apparent in betas, i.e. an attenuated link between capital and beta. From a regulatory perspective we wish to understand the effect of an exogenous increase in capital requirements. In that case, beta will fall, and then we can use the beta effects to infer the ultimate effects of higher capital. The capital data therefore is in place to estimate a reasonable lower bound for the link between capital requirements and beta, and then we can use the returns data to get at the link between beta and returns. ${ }^{8}$

\section{B. Capital Adequacy and Beta}

The channel that we are interested in is how equity affects beta. Table 3, Panel B, shows the relationship between capital measures and realized beta. The equal-weighted columns indicate that across all banks and for all capital measures, higher capital is associated with lower beta. We highlight the popular Tier 1 ratio, which generates the largest spread on beta as well as on capital. It is not surprising that the pure equity in the Tier 1 ratio (despite including some

\footnotetext{
${ }^{8}$ A more practical constraint is that fifteen years of capital data are not enough for sufficiently reliable estimates of average returns on different risk categories of banks.
} 
preferred equity) spreads beta better than other measures. Subordinated debt of the sort that is included in Tier 2, for example, provides a broader notion of capital but cannot reduce the beta of equity by nearly as much as more equity. Kashyap et al. (2010) focus on larger banks and use Computstat data on bank equity, and they document a relationship between beta and total equity to total assets. The more detailed breakdown afforded by the use of call reports data suggests that Tier 1 equity is by far the most important for spreading beta.

The value-weighted differences in Panel B show that the link between beta and capital adequacy ratios is weaker for larger banks. It is precisely in these banks where one would expect the endogenous selection of leverage to be apparent, because the asset mix is much more variable. For example a bank with a high capital ratio might nonetheless have a high beta, because it derives more profit from higher beta activities like investment banking and brokerage. Still, the difference in realized beta as a function of the Tier 1 ratio is statistically and economically meaningful even in value-weighted terms.

The significant spread in capital ratios suggests that some banks may not face binding leverage constraints, but this is misleading. We review actual regulatory requirements in the calibration, but note here that falling below regulatory minima subjects U.S. banks to Prompt Corrective Action restrictions, including ceasing dividends, filing and implementing a capital restoration plan, and prohibiting acceptance, renewal, or rolling-over of broker CDs. It may also force a return to the equity markets with an obvious lemons problem. Even falling below the higher standard of "well capitalized" triggers an increase in deposit insurance premia. Given the consequences of falling short, the overwhelming majority of banks maintain a sizable buffer over the well-capitalized boundary, not just the regulatory minimum. The precise buffer presumably varies with asset risk, perceived access to the equity market, capital structure adjustment costs, 
and other factors. In short, it is difficult to know whether bank leverage responds fully one-forone with capital requirements, but they influence even banks that are already well above heightened regulatory percentages. ${ }^{9}$

To obtain a precise estimate of the linear relationship between forward (realized) beta and equity capital we can go beyond decile sorts. For idiosyncratic risk in particular, which cancels out in portfolios, we must look at the full cross section of beta and root mean squared error measured at the stock level. Table 4 shows regression results of forward beta and idiosyncratic risk on inverse equity capital, the specification suggested by equation (1), for all banks. We use the Fama-MacBeth (1973) procedure, which gives equal weight to each cross section, in the estimation, and we also use two-dimensional clustering, which corrects the standard errors of a single regression for correlated residuals for different time periods for the same firm or for different firms at a point in time. Figure 3 shows a third approach to tease out some of the nonlinear effects in Figure 2. These are kernel regressions of the same relationship for all banks and for banks only in the top half by market capitalization.

Recall the discussion of the predictions in Figure 2. If variation in leverage were exogenous and debt were riskless, we would expect the slope in a regression of equity betas on inverse capital ratios to equal the average bank asset beta, and we would expect the intercept to be exactly zero. Both endogenous leverage choices and measurement error in capital cause the slope to be attenuated and the intercept to be positive. Consistent with measurement error, we find lower slopes for cruder measures of assets and equity capital. Consistent with the presence of endogenous leverage choices, the intercept is somewhat greater than zero even for the Tier 1 to risk-weighted assets ratio and there is attenuation in the slope in Figure 3 for very low levels

\footnotetext{
${ }^{9}$ We are grateful to Sam Hanson for the discussion in this paragraph.
} 
of leverage. A rough correction is to run this regression while forcing the intercept to be zero.

This raises the lower bound estimate for asset beta to 0.074 , which is the measured slope of the line in Panel A of Figure 3.

This will be convenient for benchmarking in our calibration below. If bank assets have an inherent beta of 0.074 and the CAPM holds in frictionless capital markets, the pre-tax weighted average cost of capital for banks should have exceeded the risk free rate by 0.074 times the market risk premium, or approximately 40 basis points annually (= $45 \times 12 \times 0.074)$ using the market risk premium from Ken French’s data library of 45 basis points per month from July 1971 through December 2011. This matches the estimation period that we will use below and roughly corresponds to the approach in Damadoran (2012). ${ }^{10}$ For the full CRSP history and the same asset beta, the corresponding figure was 57 basis points annually.

In results available upon request, we confirm the relationships between capital and future beta using Compustat's reported Tier 1 capital ratio (CAPR1Q) and total risk-based capital ratio (CAPR3Q). The slope coefficients and explanatory power are slightly lower in the Compustat data, suggesting that the call reports data is slightly more accurate.

Finally, the bottom panels of Table 4 show that greater capital is also associated with higher idiosyncratic risk, at least for capital measures scaled by risk-weighted assets. The strongest relationship is between idiosyncratic risk and total risk-based capital to risk-weighted assets, which, like Tier 1 capital to risk-weighted assets, also spreads beta well. Overall, capital ratios are somewhat more tightly linked to beta than to idiosyncratic risk.

\footnotetext{
${ }^{10}$ Damodaran's approach is simple, but it is easy to find higher or lower estimates based on other methodologies or samples. The equity premium "puzzle" literature regards the historical premium as too high to be explained with standard intertemporal models (Mehra and Prescott (1985)). See Mehra (2008) for an overview.
} 


\section{The Low Risk Anomaly Within Banks}

The data clearly show that raising capital requirements would reduce the equity beta of banks. This is consistent with the textbook Modigliani-Miller argument and essentially mechanical. The next question is whether this can be expected to reduce the cost of equity, as theory also predicts. Here the theory is not quite as strong, because it relies on the efficient pricing of CAPM risks across banks. The empirical alternative is that there is a low risk anomaly in banks, just as there has been in nonfinancial firms.

Table 5 runs cross-sectional Fama-MacBeth regressions of monthly returns on beta deciles. Under the CAPM, the coefficient on beta should reveal the market risk premium. Because of measurement error and skewness in beta, book-to-market, and momentum, we run these regressions using deciles instead of raw values. Because we are using beta deciles, not beta per se, an approximate relationship to keep in mind is from Table 2, which suggests that a movement of about seven deciles corresponds to an increase in pre-ranking beta of 1.2 and a difference in realized portfolio betas shown below of approximately 0.6 .

In the univariate regression of returns on beta decile alone, however, the point estimate is actually negative. Adjusting the point estimate to be in units of beta thus does not help us get to a plausible market risk premium. In the multivariate regression where we make the conservative assumption that size, book-to-market, and return momentum are risk factors that need to be controlled for, we also fail to find any meaningful relationship between beta and returns. For example, adjusting the point estimate to be in units of realized beta implies an implausibly small market risk premium of around 1\% per year. This is far lower than realized market returns over the same or longer periods, not to mention that the difference is statistically indistinguishable from zero. 
In Table 6, we follow beta-sorted portfolios, and once again find no evidence of a positive relationship between beta and returns. As in Table 2, we divide stocks into three groups according to pre-ranking beta. Sorting stocks leads to a reliable difference in realized portfolio betas. The low beta, value-weighted portfolio has a realized beta of 0.71 and the high beta portfolio has a beta almost twice as high at 1.27. These differences in risk should in theory lead to higher average returns over a period when equity returns overall were positive. Yet, the monthly returns in excess of the riskless rate are actually 16 basis points per month higher for the lowest beta group than for the highest beta group. Risk-adjusted underperformance is mechanically much greater. For a basic market model, the underperformance rises to 41 basis points per month. For a Fama-French three-factor model, the underperformance rises further to 46 basis points per month. Equal weighting stocks within each portfolio does not alter these impressions. The raw return differences are smaller at 0.9 basis points, and the comparable riskadjusted figures are 28 and 47 basis points per month.

While these risk-adjusted differences are economically large and statistically significant at conventional levels, the t-stats are not overwhelming. Plotting the time series in Figure 4 reveals why. There are periods where low beta stocks underperform, most notably in the late 1990s and in nonfinancial stocks, when risky stocks of all types outperformed low risk stocks. One can either view this as a brief confirmation of the CAPM or an exceptional bubble which, when removed, strengthens the conclusions of a low volatility anomaly elsewhere.

The simplest evidence that the low risk anomaly holds within banks is in the cumulative returns in Figure 4. High-beta banks underperform on a raw basis. Note that this is true over a 42-year sample - there is no suggestion that the underperformance of high beta banks can be attributed to a crisis period. Moreover, and not surprisingly, the shareholder who held high beta 
banks also experienced greater volatility. To summarize, the low risk anomaly holds within banks: for banks, lower beta has historically been associated with equal or higher, not lower, costs of equity.

Turning to idiosyncratic risk in Table 7 shows that the second side of the low risk anomaly also holds in banks. Here, the results are stronger in equal weighted portfolios. High idiosyncratic risk underperformed low idiosyncratic risk by 28 basis points per month in raw terms, 46 basis points per month in beta-adjusted returns, and 76 basis points per month in FamaFrench three-factor model adjusted returns. Qualitatively similar but quantitatively smaller patterns obtain for value-weighted portfolios. Examining idiosyncratic returns has an important side benefit. As mentioned earlier, large banks have higher beta but lower idiosyncratic risk. The fact that the returns (and leverage) results are similar for both measures suggests that the conclusions apply both to large and small banks. It also suggests the interpretation that the threefactor results are statistically stronger precisely because they remove extra random variation that arises from the exposure to the Fama-French size factor, isolating the low risk anomaly from the size anomaly.

A final set of robustness checks appears in Table 8, where we extend the sample back to 1931 for beta-sorted portfolios and idiosyncratic risk sorted portfolios, and we show results for the full sample of CRSP stocks. The important things to note are that the low risk anomaly is as large economically in the full sample as in the most recent 40 years, and that results within banking stocks alone are consistent with the low risk anomaly found in earlier research using the entire CRSP sample. 


\section{Calibration}

We now explore the quantitative effects of a hypothetical shift in capital requirements on the spread between banks’ weighted average cost of capital and the riskless rate. We first review the current regulatory environment to provide some context. We then proceed in three steps. First, we consider the simple case where there is a low risk anomaly in equities, but banks are otherwise able to raise risk-free and correctly priced debt. We also relax the assumption of riskfree debt, but retain the assumption of efficiency in the debt market. Second, we layer on the possibility of a low risk anomaly for debt as well as equity securities. Third, we briefly consider the effects of a government guarantee on bank debt.

\section{A. Regulatory Background}

Bank capital regulations continue to evolve both in the United States and worldwide. While countries have differed in the speed of reforms and their implementation details, the broad international trend has been toward increased capital requirements. Basel I, agreed in 1988, defined Tier 1 and Tier 2 capital as well as risk-weighted assets, and required a minimum of Tier 1 capital to risk-weighted assets of $4 \%$ and a total of Tier 1 and Tier 2 capital of $8 \%$ (ratios here and below are also scaled by risk-weighted assets unless otherwise specified). Basel II, agreed in 2006, attempted to address deficiencies of Basel I by modifying the risk-weighting scheme and introducing a 2\% requirement of common-only Tier 1 capital. Basel III, developed in 2011, further revised the definitions of risk-weighted assets, raised the required common Tier 1 ratio to between $7 \%$ to $9.5 \%$ depending on market conditions, raised the required Tier 1 ratio to between $8.5 \%$ to $11 \%$, and raised the total capital requirement to between $10.5 \%$ and $13 \%$. As a backstop, Basel III also introduces a minimal requirement of 3\% leverage ratio, defined as Tier 1 
capital to total (non-risk weighted) assets. (The U.S. Federal Reserve had long maintained a minimal leverage ratio requirement of 4\%.) The U.S. Federal Reserve intends to transition to essentially the Basel III rules in phases, with full implementation now expected in $2019 .^{11}$

Such regulations are the outcome of interactions among regulators, politicians, investors, and bankers, each with somewhat different preferences and proposals, some of which would raise the common Tier 1 ratio all the way up to 30\% (Elliott (2013)). Accordingly, we follow Kashyap et al. (2010) and assume that regulators impose a 10\% increase of capital requirements in the form of common equity. We assume that this is a fully binding and immediate increase from current levels. But it might, very roughly speaking, be viewed as the difference between a benchmark with no capital requirements and the current regime. We emphasize that we do not estimate the effect of any specific reform proposal, but our hypothetical change is nonetheless in an empirically relevant range in light of various policy proposals.

We focus on capital requirements in this paper, but it is worth noting that liquidity requirements of the sort called for in Basel III may also activate the low risk anomaly. Holding cash or highly liquid instruments reduces asset beta and overall risk, thus equity beta and idiosyncratic risk, which may then increase the cost of bank equity.

\section{B. The Effect of Increased Capital Requirements on the Weighted Average Cost of Capital}

We start by supposing that the CAPM holds, but with a low risk anomaly. In other words, higher beta equities underperform their CAPM benchmark and lower beta equities outperform their CAPM benchmark. In particular, returns are assumed to take the following linear form: $r_{i}=\left(\beta_{i}-1\right) \gamma+r_{f}+\beta_{i} r_{p}$,

\footnotetext{
${ }^{11}$ See Saunders and Cornett (2010) and Yang (2012) for details on the recent history of banking regulation.
} 
where $\beta_{i}$ is the $\beta$ of any equity $i, r_{f}$ is the risk free rate, $r_{p}$ is the market risk premium, and $\gamma=\frac{d \alpha}{d \beta}<0$ measures the extent of the low risk anomaly. Note that Baker et al. (2011) derive a pricing equation of exactly this form when investment is delegated to an investment manager with a typical information-ratio objective. (That is, to maximize the return on the portfolio in excess of a benchmark divided by the standard deviation of the portfolio return over the benchmark.) Also assume that debt is correctly priced by the CAPM at: $r_{i}=r_{f}+\beta_{d} r_{p}$

We relax this assumption in an extension below.

The cost of capital for a bank is the weighted average of the cost of debt $r_{d}$ and the cost of equity $r_{e}$ :

$W A C C=e r_{e}+(1-e) r_{d}$,

where $e$ is the ratio of equity to total assets. We can then substitute equation (2) and equation (3) into equation (4), and simplify:

$W A C C=e\left(\beta_{e}-1\right) \gamma+r_{f}+\beta_{a} r_{p}$,

where $\beta_{a}$ is the $\beta$ of the banks' operating assets which we assume is invariant to its capital structure.

We are interested in how the cost of capital changes with a change in capital requirements that moves the bank from its old level of capital $e$ to a new regulatory level $e^{*}$. Differencing equation (5), evaluated at the new and old levels of capital, and substituting out the equity beta, leads to the following increase in the cost of capital:

$$
\Delta W A C C=e^{*}\left(\beta_{e^{*}}-1\right) \gamma-e\left(\beta_{e}-1\right) \gamma=\gamma\left[e-e^{*}+(1-e) \beta_{d}-\left(1-e^{*}\right) \beta_{d^{*}}\right] \equiv \gamma\left(e-e^{*}+A\left(e, e^{*}\right)\right) .
$$


A special case is when the debt is riskless, in both capital regimes, so that $\beta_{d}=\beta_{d^{*}}=0$. This means that the change in the cost of capital is simply $\gamma\left(e-e^{*}\right)$, which is greater than zero for increases in the ratio of equity $e$. In general, we believe that the effects of changing debt betas are likely to be small. Given that bank equity betas are somewhat less than 1.0 on average, and equity ratios are in the range of 8 to 19 percent in Table 3, estimates of $\beta_{a}$ for banks are quite small, estimates of $\beta_{d}$ are by definition smaller, and differences in $\beta_{d}$ are smaller still. Even so, this simplified measure of the change in the cost of capital under the assumption of riskless debt should be viewed as an upper bound. The term $A\left(e, e^{*}\right)$ is greater than zero when $e>e^{*}$. When debt shares the asset risk with equity, the impact of an increase in capital requirements on equity betas is mitigated somewhat.

We can use Table 4 to get a rough sense of the size of $\gamma=\frac{d \alpha}{d \beta}$. In Figure 5 Panel A, we plot the estimated alphas and betas from Table 6, separately for CAPM and Fama-French three factor regressions. The CAPM betas range from 0.56 for an equal-weighted portfolio of low beta banks to 1.27 for a value-weighted portfolio of high beta banks. The corresponding three factor betas range from 0.55 to 1.32 . The portfolio alphas range from -48 basis points per month for the value-weighted portfolio of high beta banks, controlling for the size and book-to-market factors, to 34 basis points per month for the equal-weighted portfolio of low beta banks, controlling only for the market factor. The figure shows simple regressions of alpha on beta for the two sets of portfolio alphas and betas. The historical slope estimates of $\gamma=\frac{d \alpha}{d \beta}$ are -68 and -75 basis points per month.

Assuming riskless debt, this assumed linear relationship between beta and alpha indicates that a 10 percentage point increase in required equity capital would be associated with an 82 (= 
$68 \times 12 \times 0.1$ ) to 90 basis point increase in the weighted average cost of capital, and, assuming competitive lending markets, a corresponding increase in spreads.

As a robustness test, Panel B plots the analogous results from Table 6-style regressions that exclude two prominent crisis periods, October 1989 through October 1990 and January 2007 through February 2009. It is not the case that the underperformance of high-beta banks is due to exceptionally poor performance during crises, and the anomaly is roughly linear whether one includes or excludes such periods.

Finally, in Figure 6 we substitute the data from Table 6 with comparable estimates using the entire CRSP universe of financial and nonfinancial firms. If anything, the low risk anomaly is actually stronger in banks than nonfinancial firms. Using the linear, all-CRSP slope estimates, a 10 percentage point increase in required equity capital is associated with a weighted average cost of capital increase of 61 to 65 basis points. So, the range of estimates using a linear empirical model of only banking stocks or all US stocks and using a simple CAPM or a three-factor model, is from 60 to 90 basis points.

\section{C. $\quad$ Extension 1: Adding a Low Risk Anomaly for Debt}

The calibration is greatly simplified with the assumption of fairly priced and riskless debt. The important assumption, though, is not that debt is riskless but that the debt and equity markets are not efficiently integrated. If the two markets are integrated and a single equation (2) governs the pricing of debt and equity, then the Modigliani and Miller theorem is restored and the cost of capital for banks is simply equal to:

$$
W A C C=\left(\beta_{a}-1\right) \gamma+r_{f}+\beta_{a} r_{p} \text {, }
$$


which is independent of the chosen capital structure $e$. Given the magnitude of the low risk anomaly within equity markets, this sort of debt market integration suggests an implausibly large expected return on debt. An investment grade debt security, say with a beta equal to 0.1 , would have an expected alpha of $0.9 \times 68=61$ to $0.9 \times 75=68$ basis points per month according to equation (2) and Figure 5, and all debt securities, with $\beta$ s well below 1, would offer large, riskadjusted expected returns. Spreads on corporate debt are smaller than this by an order of magnitude, so integrated markets of this sort are not likely to be empirically relevant.

More plausible is a low risk anomaly that holds within each asset class, along the lines of Frazzini and Pedersen (2013), but not across asset classes. Baker, Bradley, and Wurgler (2012) emphasize that an upward sloping risk and return relationship holds at the level of asset classes, ranging from government securities to small cap stocks. This means equation (3) could be modified as follows:

$r_{d}=\left(\beta_{d}-\bar{\beta}_{d}\right) \gamma_{d}+r_{f}+\beta_{d} r_{p}$,

where it is the difference of an individual debt security's $\beta_{d}$ from the average of all debt securities (not 1) that determines the extent of mispricing. Now the overall cost of capital equals: $W A C C=e\left(\beta_{e}-1\right) \gamma+(1-e)\left(\beta_{d}-\bar{\beta}_{d}\right) \gamma_{d}+r_{f}+\beta_{a} r_{p}$.

The analogue of equation (6), the change in the cost of capital as leverage changes, is:

$$
\Delta W A C C=\gamma\left[e-e^{*}+A\left(e, e^{*}\right)\right]+\gamma_{d}\left[-A\left(e, e^{*}\right)-\left(e-e^{*}\right) \bar{\beta}_{d}\right]=\left(e-e^{*}\right)\left(\gamma-\bar{\beta}_{d} \gamma_{d}\right)+A\left(e, e^{*}\right)\left(\gamma-\gamma_{d}\right) .
$$

An analytically simple special case is when the extent of the low risk anomaly per unit change in $\beta$ is the same within each asset class, so that $\gamma=\gamma_{d}$. This means that the change in the cost of capital is simply $\gamma\left(e-e^{*}\right)\left(1-\bar{\beta}_{d}\right)$, which is greater than zero for increases in the ratio of equity $e$. 
The terms that depend on the change in the debt beta drop out, because there are exactly offsetting effects. On the one hand, the debt becomes safer, sharing some of the risk reduction in equity as leverage decreases and thus mitigating the increase in the cost of equity. This is the impact shown within the first term of equation (10), multiplied by $\gamma$, and it arises because the equity beta falls less than linearly in the inverse of the leverage ratio, and the cost of capital rises by less than in the case of riskless debt. On the other hand, because there is less of the now safer, lower $\beta$, debt, the cost of capital rises by more than in the case of riskless debt. Because of the low risk anomaly within the debt markets, safer debt is more expensive on a risk-adjusted basis. These two effects offset exactly, when the extent of the low risk anomaly is the same within the two asset classes. When the low risk anomaly is smaller in debt markets, the effect of changing debt betas on mitigating the rise in the cost of equity is larger, so that an increase in capital increases the cost of capital by less than in the case where $\gamma=\gamma_{d}$ and the simplified expression is an upper bound effect.

The simplified expression $\gamma\left(e-e^{*}\right)\left(1-\bar{\beta}_{d}\right)$ contains an extra term added to the case of correctly priced, riskless debt. It measures the extent to which the two markets are not integrated, in other words the difference between the pricing of debt and equity in equations (2) and (7) versus (8). If the markets are perfectly integrated, so that $\bar{\beta}_{d}=1$, then the Modigliani and Miller theorem holds. If there is a separate low risk anomaly within each asset class, so that $\bar{\beta}_{d}<<1$, the effects are slightly smaller than in the riskless debt case. 


\section{Extension 2: Adding Government Subsidies}

The analysis so far considers situations where the government is not involved in insuring the debt of banks. Deposit insurance means that a bank can issue risky debt at the riskless rate of return. It means equation (3) for the pricing of debt can be modified to:

$r_{i}=-\beta_{d} r_{p}+r_{f}+\beta_{d} r_{p}=r_{f}$

For the bank, the result is something very similar to the riskless case, except that the debt, despite being priced as riskless, shares some of the risk of equity, mitigating the effect of the low risk anomaly on the cost of equity:

$\Delta W A C C=\gamma\left[e-e^{*}+A\left(e, e^{*}\right)\right]-r_{p}\left[-A\left(e, e^{*}\right)\right]=\gamma\left(e-e^{*}\right)+A\left(e, e^{*}\right)\left(\gamma+r_{p}\right)$.

If $\gamma=-r_{p}$, which is empirically not far from the estimates derived for $\gamma$, then the effect on bank cost of capital is the same as it was in the riskless case. Again, there are two offsetting effects for the bank. As $r_{p}$ increases, the effect of leverage on the cost of capital is larger than in the riskless case. This is intuitive: lower leverage means that the bank gets a smaller subsidy from the government. There is less debt overall and the debt that remains requires a smaller subsidy. As $\gamma$ increases in absolute value, the effect of leverage on the cost of capital is smaller than in the riskless case. This is because the impact of debt sharing in the risk of equity is magnified relative to the riskless case where there is no risk sharing.

Another conclusion from equation (12) is that the government subsidy falls, of course, as capital increases, but there is an additional increase in the cost of capital that is not zero-sum between the government and banks, because their cost of equity capital increases. 


\section{E. Summary of the Calibration Exercise}

To sum up, as long as the debt and equity markets are not integrated, heightened capital markets will ceteris paribus increase the weighted average cost of capital for banks, in the presence of a low volatility anomaly. Table 9 summarizes the theoretical analysis. In every situation where capital markets are segmented, the basic effect is simply the product of the percentage point increase in equity capital times the excess risk-adjusted performance per unit of beta. Reasonable point estimates for these effects are in the range of 60 to 90 basis points, depending on whether we rely on the general pattern in all stocks or the experience of banks alone. These are attenuated in the case of risky debt or when there is a corresponding, but segmented low volatility anomaly in debt markets. But, we believe this attenuation is slight, in large part because bank debt betas overall are likely to be small.

It is worth putting 60 and 90 basis points in comparative perspective. Recall that our asset beta estimate for banks was 0.074 . With the historical risk premium, this suggests a pre-tax weighted average cost of capital under the CAPM of around 40 basis points per year above the risk-free rate over the same 40 year period. Relative to this spread, the effects of significantly heightened capital requirements when combined with the historical low volatility anomaly are large indeed. They suggest more than doubling the weighted average cost of capital, when it is measured as a premium over the risk-free rate.

\section{Conclusion}

Regulators and bankers are concerned about the effect of capital requirements on the cost of capital and lending rates. Standard theory argues that this is naïve in perfect and efficient 
capital markets, because increased capital will reduce the beta and thus the cost of equity, leaving the overall cost of capital unchanged.

We find that this theory does not match the data on stock returns for banks. While the evidence does show that less leverage reduces equity risk, this in turn puts the low risk anomaly into play. In our sample, lower risk banks have the same or higher returns than higher risk banks. Unless long-term and worldwide patterns are reversed, reducing equity beta will not reduce the cost of equity. In a simple calibration that uses the historical pattern between risk and return, we find that a ten percentage-point increase in the required Tier 1 capital to risk-weighted assets ratio would have increased the overall cost of capital by as much as 90 basis points. Given the relatively low estimate for the beta of bank assets overall, this would more than double the spread of the cost of capital over the risk-free rate. Alone or in concert with other cost-of-capital effects of heightened capital requirements, such as the loss of tax benefits in Kashap, Stein, and Hanson (2010), such an effect would put banks at a larger competitive disadvantage relative to the shadow banking system, provided it is not similarly regulated. ${ }^{12}$

We repeat the qualification given in the introduction. When all other private and social costs and benefits are totaled up, heightened capital requirements may well remain desirable. Our contribution here is to point out that the low volatility anomaly presents an underappreciated and potentially significant cost that needs to be added to the debate.

\footnotetext{
${ }^{12}$ See Adrian and Ashcraft (2012) for a broad overview of approaches to shadow banking regulation.
} 


\section{References}

Admati, Anat R., DeMarzo, P. M., Hellwig, M. F., and P. C. Pfleiderer. "Fallacies, Irrelevant Facts, and Myths in the Discussion of Capital Regulation: Why Bank Equity is Not Expensive.” Stanford University working paper (2011).

Admati, Anat R., M. Hellwig. The Bankers’ New Clothes. Princeton: Princeton UP (2013).

Adrian, Tobias, A. B. Ashcraft. “Shadow Banking Regulation.” Federal Reserve Bank of New York Staff Report No. 559 (2012).

Ang, Andrew, R. Hodrick, Y. Xing, X. Zhang. "The Cross-Section of Volatility and Expected Returns.” Journal of Finance 61 (2006), pp. 259-299.

-. "High Idiosyncratic Volatility and Low Returns: International and Further U.S. Evidence." Journal of Financial Economics 91 (2009), pp. 1-23.

Baker, Malcolm, B. Bradley, R. Taliaferro. “The Low Risk Anomaly: A Decomposition into Micro and Macro Effects.” Harvard Business School, working paper (2013).

Baker, Malcolm, B. Bradley, J. Wurgler. "Benchmarks as Limits to Arbitrage: Understanding the Low-Volatility Anomaly.” Financial Analysts Journal 67 (2011), pp. 40-54.

Bali, Turan, N. Cakici, R. Whitelaw. "Maxing Out: Stocks as Lotteries and the Cross-Section of Expected Returns.” Journal of Financial Economics 99 (2011), pp. 427-446.

Barberis, Nicholas, M. Huang. "Stocks as Lotteries: The Implications of Probability Weighting for Security Prices.” American Economic Review 98 (2008), pp. 2066-2100.

Basel Committee on Banking Supervision. "An Assessment of the Long-term Economic Impact of Stronger Capital and Liquidity Requirements.” Bank for International Settlements mimeo (2010).

Black, Fischer. “Capital Market Equilibrium with Restricted Borrowing.” Journal of Business 45 (1972), pp. 444-455.

Black, Fischer, M. C. Jensen, M. Scholes. "The Capital Asset Pricing Model: Some Empirical Tests.” In M. C. Jensen, ed., Studies in the Theory of Capital Markets. New York: Praeger (1972), pp. 79-121.

Blitz, David, P. V. Vliet. “The Volatility Effect: Lower Risk Without Lower Return.” Journal of Portfolio Management 34 (2007), pp. 102-113.

Blitz, David, J. Pang, P. V. Vliet. “The Volatility Effect in Emerging Markets.” Robeco Asset Management, working paper (2012). 
Brennan, Michael. “Agency and Asset Pricing.” University of California, Los Angeles, working paper (1993).

Cornell, Bradford. "The Pricing of Volatility and Skewness: A New Interpretation.” California Institute of Technology working paper (2008).

Coval, Joshua, J. Jurek, E. Stafford. “The Economics of Structured Finance.” Journal of Economic Perspectives 23 (2009), pp. 3-25.

Cummins, Jason G., K. A. Hassett, R. G. Hubbard. "A Reconsideration of Investment Behavior Using Tax Reforms as Natural Experiments.” Brookings Papers on Economic Activity 2 (1994), pp. 1-74.

Damodaran, Aswath. "Equity Risk Premiums (ERP): Determinants, Estimation and Implications - 2012 Edition.” NYU Stern School of Business working paper (2012).

Elliott, Douglas J. "Quantifying the Effects on Lending of Increased Capital Requirements.” The Brookings Institution mimeo (2009).

Elliott, Douglas J. "A Further Exploration of Bank Capital Requirements: Effects of Competition from Other Financial Sectors and Effects of Size of Bank or Borrower and of Loan Type.” The Brookings Institution mimeo (2010).

Elliott, Douglas J. "Higher Bank Capital Requirements Would Come at a Price.” Brookings Institute Internet posting. http://www.brookings.edu/research/papers/2013/02/20-bank-capitalrequirements-elliott (February 20, 2013).

Fama, Eugene F., K. R. French. "The Cross-Section of Expected Stock Returns.” Journal of Finance 47 (1992), pp. 427-465.

Fama, Eugene F., K. R. French, “Industry Costs of Equity.” Journal of Financial Economics 43 (1997), pp. 153-193.

Fama, Eugene F., J. D. MacBeth. "Risk, Return, and Equilibrium: Empirical Tests.” Journal of Political Economy 81 (1973), pp. 607-636.

Frazzini, Andrea, L. H. Pedersen. "Betting Against Beta.” NYU Stern School of Business working paper (2013).

Gilchrist, S., J. W. Sim, and E. Zakrajsek. "Misallocation and Financial Market Frictions: Some Direct Evidence from the Dispersion in Borrowing Costs." Review of Economic Dynamics 16 (2013), pp. 159-176.

Graham, John, “How Big Are the Tax Benefits of Debt.” Journal of Finance 63 (2000), pp. 19011941. 
Haugen, Robert A., A. J. Heins, "Risk and the Rate of Return on Financial Assets: Some Old Wine in New Bottles.” Journal of Financial and Quantitative Analysis 10 (1975), pp. 775-784.

Hong, Harrison, D. Sraer. “Speculative Betas.” Princeton University working paper (2012).

Ibbotson Associates, 2012, Ibbotson SBBI 2012 Classic Yearbook (Morningstar, Chicago).

Jegadeesh, Narasimhan, S. Titman, "Returns to Buying Winners and Selling Losers: Implications for Stock Market Efficiency.” Journal of Finance 48 (1993), pp. 65-91.

Karceski, Jason. "Returns-Chasing Behavior, Mutual Funds, and Beta’s Death. “ Journal of Financial and Quantitative Analysis 37 (2002), pp. 559-594.

Kashyap, Anil K., Stein, J. C., and S. Hanson. "An Analysis of the Impact of 'Substantially Heightened' Capital Requirements on Large Financial Institutions.” Harvard University working paper (2010).

Kumar, Alok. “Who Gambles in the Stock Market?” Journal of Finance 64 (2009), pp. 1889-1933.

Macroeconomic Assessment Group of the Basel Committee on Banking Supervision. “Assessing the Macroeconomic Impact of the Transition to Stronger Capital and Liquidity Requirements Final Report.” Bank for International Settlements mimeo (2010).

Mehra, Rajnish. Handbook of the Equity Risk Premium. Amsterdam: Elsevier, 2008.

Mehra, Rajnish, E. C. Prescott. “The Equity Premium: A Puzzle.” Journal of Monetary Economics 15 (1985), pp. 145-161.

Philippon, Thomas. “The Bond Market’s q.” Quarterly Journal of Economics 124 (2009), pp. 1011-1056.

Santos, Andre Oliveira, D. Elliott. “Estimating the Costs of Financial Regulation.” IMF Staff Discussion Note (2012).

Saunders, Anthony, and M. Cornett. Financial Institutions Management: A Risk Management Approach. Seventh Edition. New York: McGraw-Hill (2010).

Tversky, Amos, D. Kahneman. "Advances in Prospect Theory: Cumulative Representation of Uncertainty.” Journal of Risk and Uncertainty 5 (1992), pp. 297-323.

Van den Heuvel, Skander J. “The Welfare Cost of Bank Capital Requirements.” Journal of Monetary Economics 55 (2008), pp. 298-320.

Yang, Emily. "Bank Capital and Regulation.” Federal Reserve Bank of New York presentation http://www.newyorkfed.org/education/pdf/2012/Yang_bank_capital_regulation.pdf. (March 20, 2012). 
Figure 1. Pre-ranking Beta in the Banking Industry, Value-Weighted. Value-weighted pre-ranking beta, July 1971 through December 2011. We define the banking industry as the union of the banking SIC codes from Ken French's definition of 48 industries and the three-digit SIC 671, which includes bank holding companies. Preranking beta is computed by regressing a minimum of 24 months and a maximum of 60 months of trailing holding period returns (RET) on the corresponding CRSP value-weighted market holding period returns (VWRETD). The sample is divided into low (bottom 30\%), medium (middle 40\%), and high (top 30\%) portfolios according to preranking beta. The sample includes firms for which we can compute a valid beta, with at least 24 monthly holding period return (RET) observations, a valid market capitalization, with a nonmissing price (PRC) and shares outstanding (SHROUT) observation, and at least one holding period return following a valid beta.

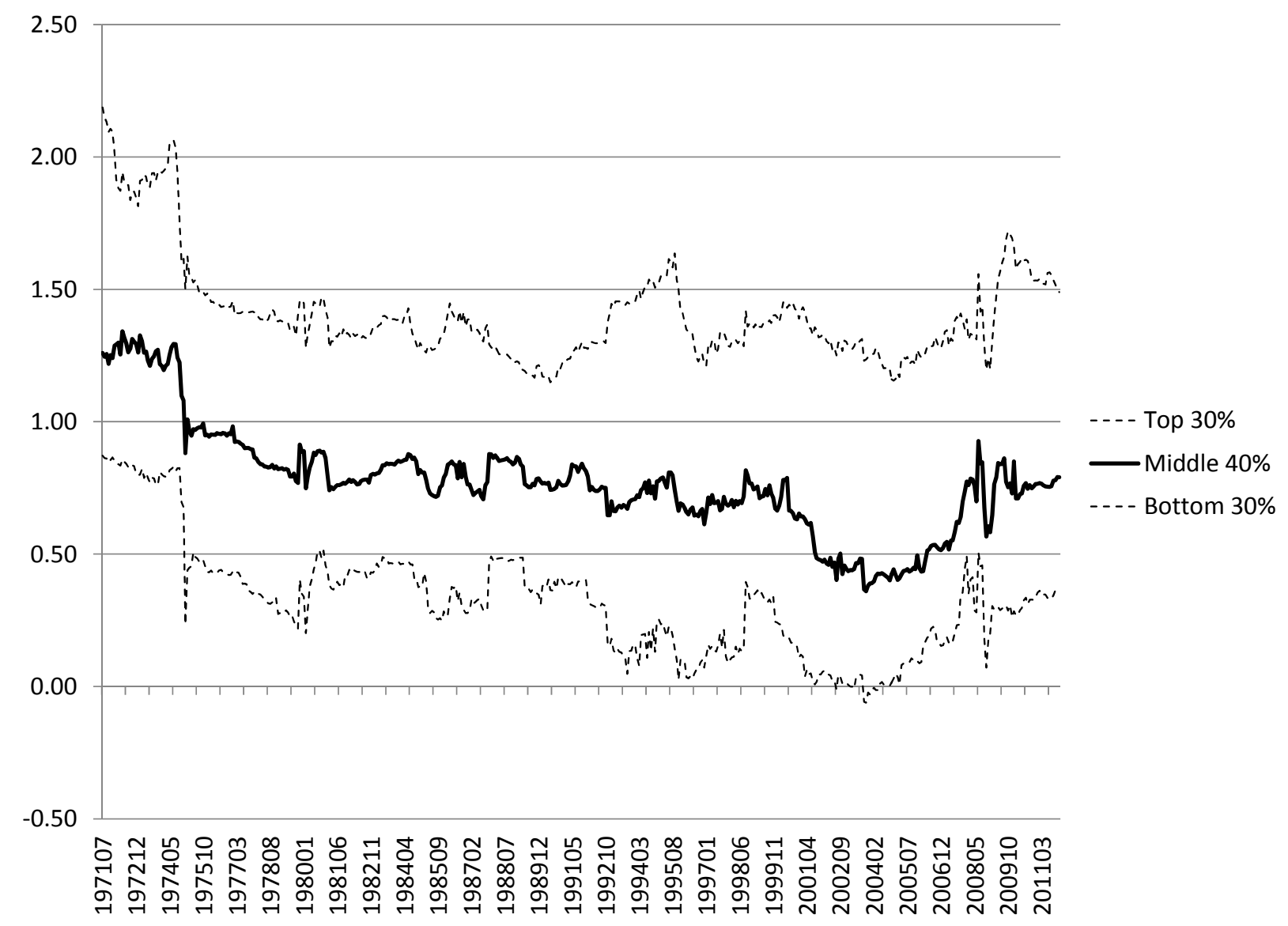


Figure 2. Bank Capital and Beta: Empirical Predictions. Exogenous changes in the inverse capital ratio on the xaxis should be associated linearly with increases in equity beta if the changes in capital are exogenous and the debt is approximately risk free. The slope is equal to the asset beta. Endogenous leverage choice, where a bank chooses higher or lower leverage to match its asset beta risk, or risky debt will both tend to flatten the predicted relationship.

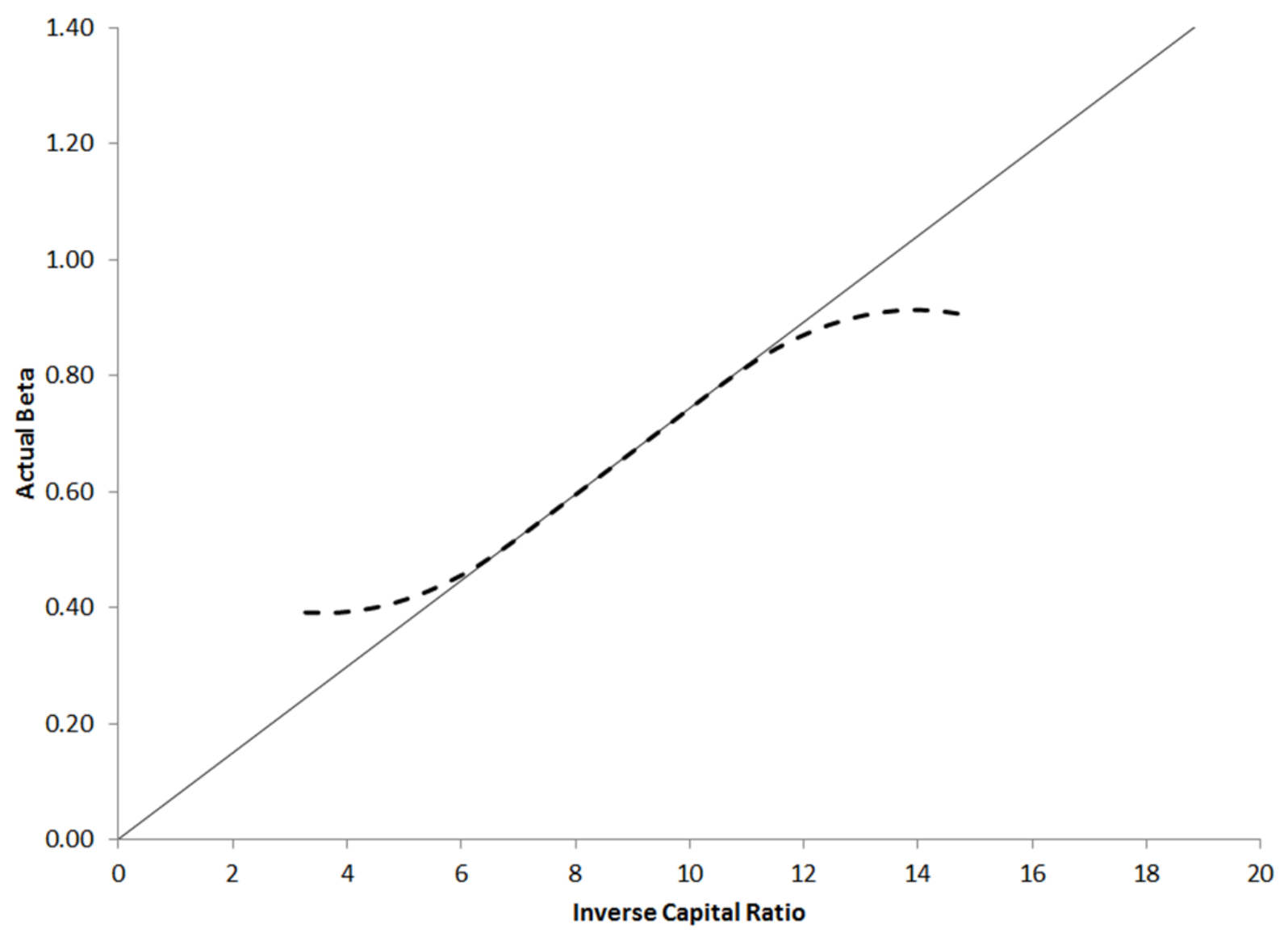


Figure 3. Kernel regressions of future beta on the inverse capital ratio. The dependent variable is the forward beta, computed by regressing a minimum of 24 months and a maximum of 60 months of future holding period returns (RET) in excess of the riskless rate on the corresponding CRSP value-weighted market holding period returns (VWRETD, also in excess of the riskless rate). The independent variable is the ratio of total risk-based capital (RCFD3792) to Tier 1 capital (RCFD8274). Panel A includes all banks. Panel B includes only banks above the median market capitalization in each month. The local polynomial regressions use a Epanechnikov kernel, with 20 bins and smoothing interval of 0.1 .

Panel A. All banks

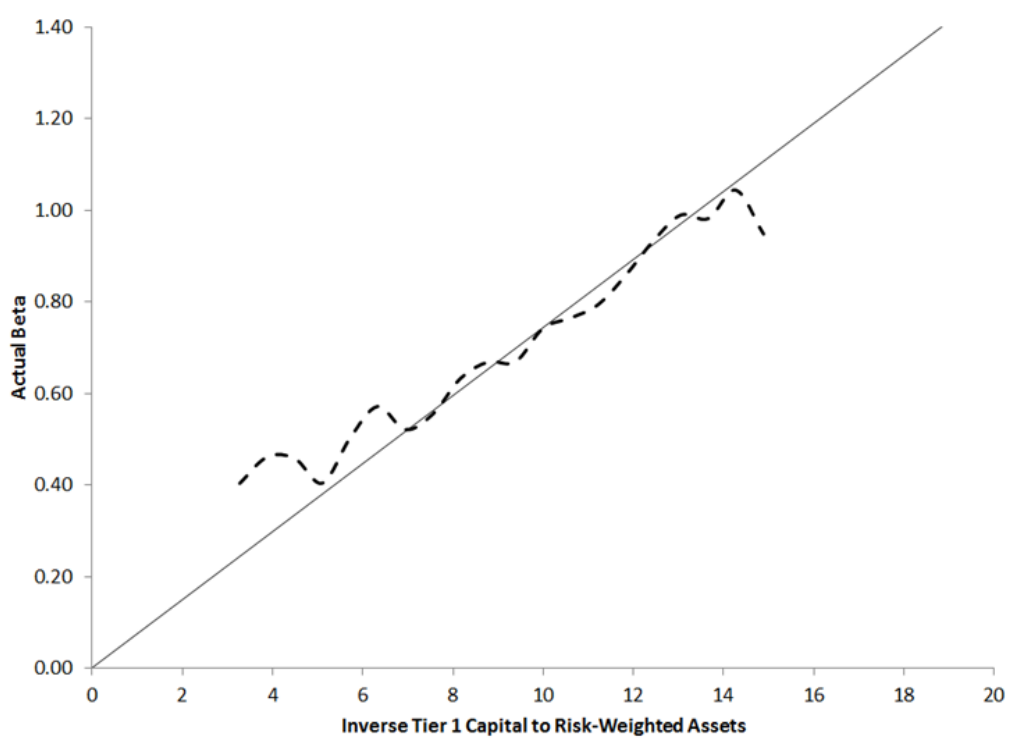

Panel B. Large banks

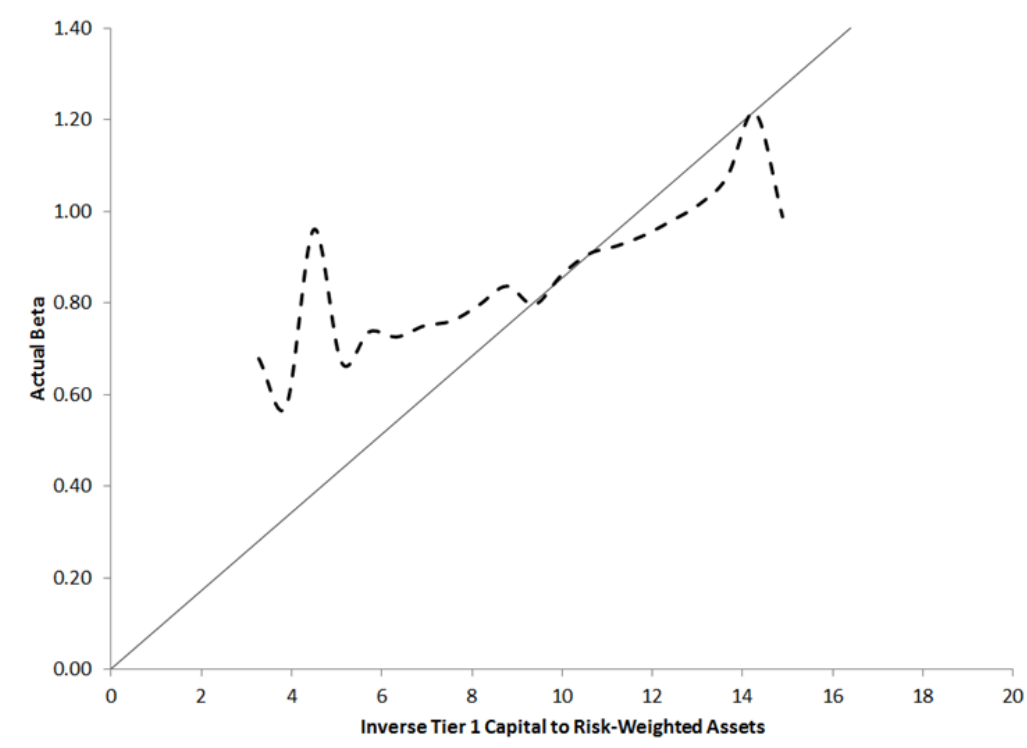


Figure 4. Beta Sorted Portfolio Returns. Portfolio returns for low, medium, and high beta bank stocks. Each portfolio total return in excess of the riskless rate is computed using either equal or value weights. The sample is divided within each month into low (bottom 30\%), medium (middle 40\%), and high (top 30\%) portfolios according to pre-ranking beta. Pre-ranking beta and the sample are described in Table 2.

Panel A. Equal Weighted Portfolio

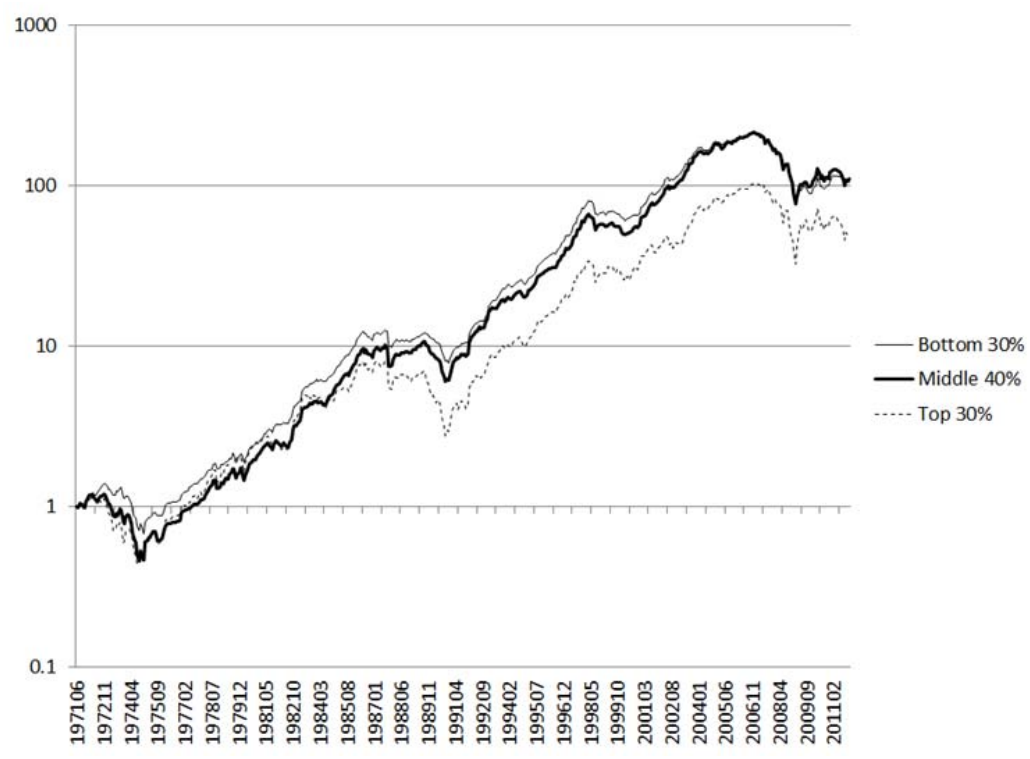

Panel B. Value Weighted Portfolio

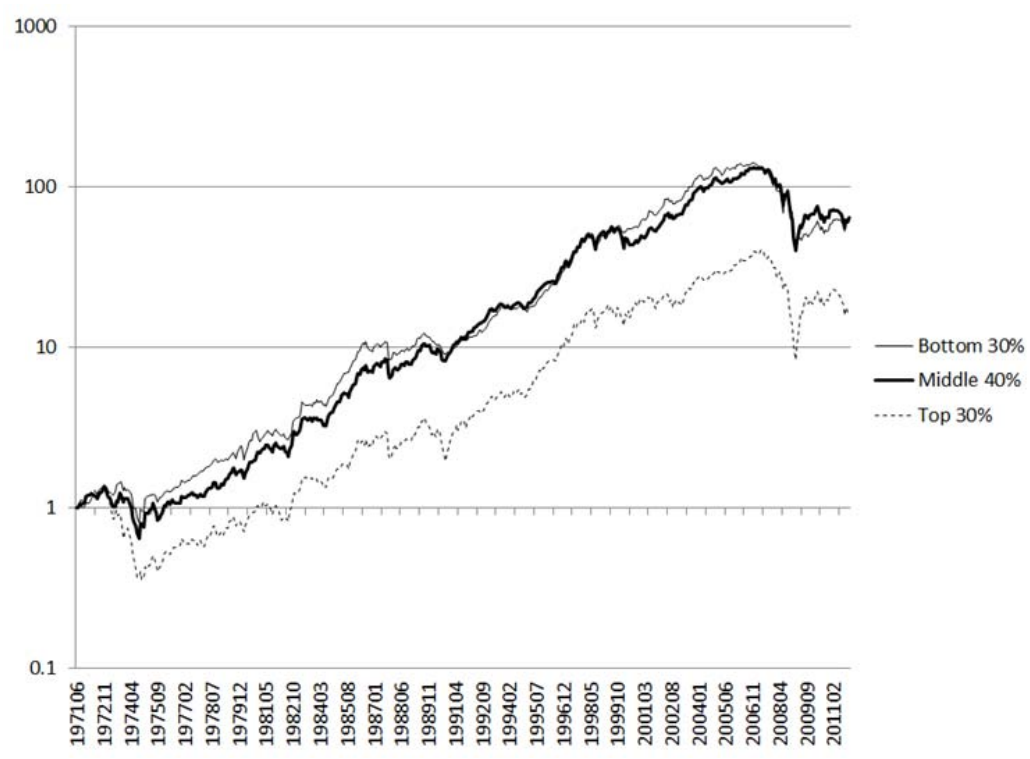


Figure 5. The Estimated Size of the Low Risk Anomaly in the Banking Industry. Plots of CAPM and FamaFrench 3-Factor alpha and beta for six portfolios. The alphas and betas are described in Table 6. Slopes from linear regressions of alpha on beta are shown on the plots. Panel A shows the results for the banking industry as defined in Table 1. Panel B excludes the peak to trough periods in the middle bank portfolio from October 1989 through October 1990 and from January 2007 through February 2009. Excluding the periods of poor ex post performance increases the alpha estimates.

Panel A. Banks

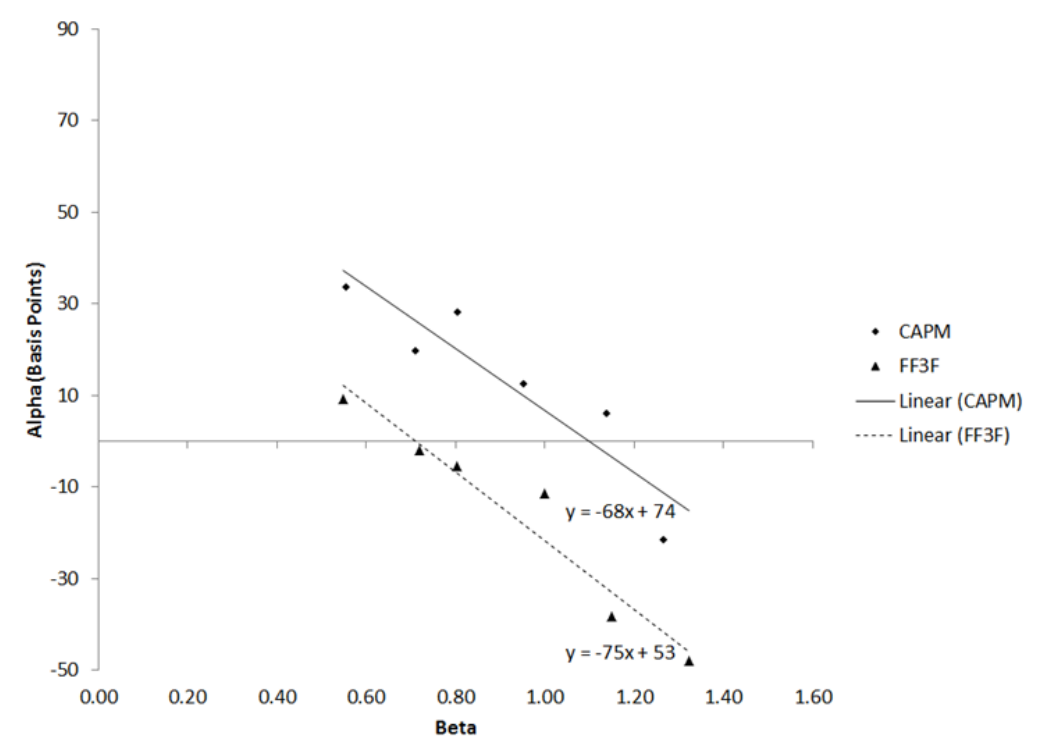

Panel B. Banks, Excluding Two Crisis Periods

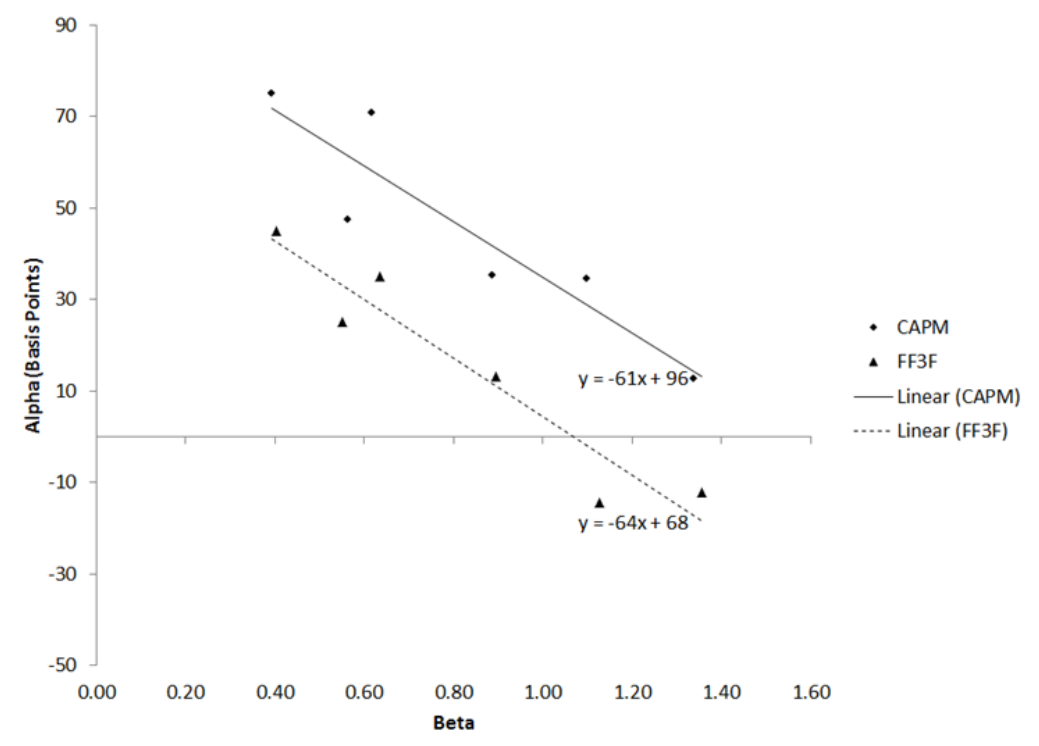


Figure 6. The Estimated Size of the Low Risk Anomaly for All Firms. Plots of CAPM and Fama-French 3Factor alpha and beta for six portfolios. The alphas and betas are estimated as in Table 6, but for all CRSP firms. Slopes from linear regressions of alpha on beta are shown on the plots.

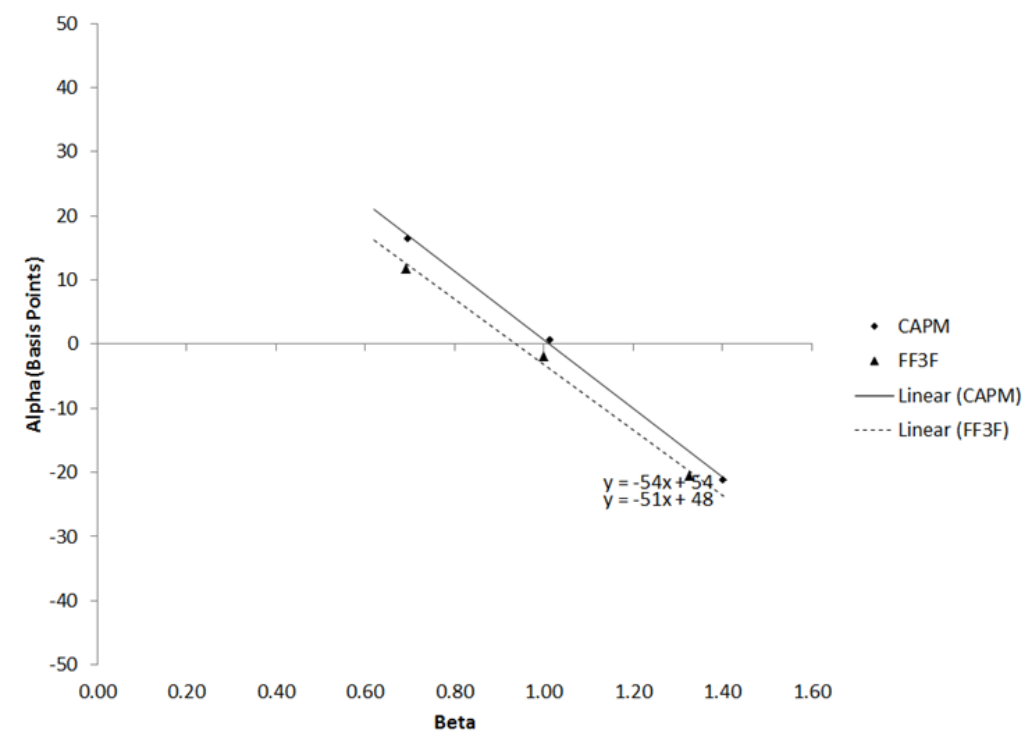


Table 1. Banking Industry. Number of firms in each industry group by decade and overall, July 1971 through December 2011. We define the banking industry as the union of the banking SIC codes from Ken French's data library definition of 48 industries and the three-digit SIC 671, which includes bank holding companies. The sample includes firms for which we can compute a valid beta, with at least 24 monthly holding period return (RET) observations, a valid market capitalization, with a nonmissing price (PRC) and shares outstanding (SHROUT) observation, and at least one holding period return following a valid beta. There are relatively few publicly traded banks in the first half of the CRSP sample, so we focus on the second half, using July 1971 as a start date. Table 8 shows the full sample as a robustness check.

\begin{tabular}{|c|c|c|c|c|c|c|}
\hline \multirow[b]{2}{*}{ SIC Code } & \multirow[b]{2}{*}{ Industry } & \multicolumn{5}{|c|}{ CRSP Firms } \\
\hline & & $\begin{array}{r}1971- \\
1979\end{array}$ & $\begin{array}{r}1980- \\
1989\end{array}$ & $\begin{array}{r}1990- \\
1999\end{array}$ & $\begin{array}{r}2000- \\
2011\end{array}$ & Total \\
\hline $6000-6000$ & Depository institutions & 0 & 0 & 1 & 2 & 3 \\
\hline $6020-6020$ & Commercial banks & 1 & 213 & 465 & 334 & 597 \\
\hline 6021-6021 & National commercial banks & 0 & 4 & 51 & 144 & 165 \\
\hline $6022-6022$ & State banks - Fed Res System & 13 & 30 & 76 & 229 & 276 \\
\hline $6023-6024$ & State banks - not Fed Res System & 15 & 31 & 7 & 0 & 33 \\
\hline $6025-6025$ & National banks - Fed Res System & 62 & 120 & 45 & 4 & 131 \\
\hline $6026-6026$ & National banks - not Fed Res System & 0 & 1 & 2 & 0 & 2 \\
\hline $6027-6027$ & National banks, not FDIC & 0 & 1 & 0 & 0 & 1 \\
\hline $6028-6029$ & Banks & 1 & 1 & 7 & 46 & 48 \\
\hline $6030-6036$ & Savings institutions & 0 & 142 & 463 & 427 & 674 \\
\hline $6040-6059$ & Other Banks & 4 & 11 & 5 & 1 & 13 \\
\hline $6060-6062$ & Credit unions & 0 & 0 & 10 & 1 & 10 \\
\hline $6120-6129$ & S\&Ls & 29 & 130 & 20 & 4 & 142 \\
\hline $6130-6139$ & Agricultural credit institutions & 0 & 1 & 1 & 0 & 1 \\
\hline $6140-6149$ & Personal credit institutions (Beneficial) & 23 & 21 & 47 & 40 & 92 \\
\hline $6150-6159$ & Business credit institutions & 9 & 33 & 56 & 56 & 115 \\
\hline $6160-6169$ & Mortgage bankers & 16 & 34 & 68 & 52 & 119 \\
\hline $6170-6179$ & Finance lessors & 0 & 0 & 3 & 1 & 3 \\
\hline 6190-6199 & Financial services & 0 & 2 & 3 & 2 & 7 \\
\hline \multirow[t]{2}{*}{$6710-6719$} & Holding offices & 315 & 852 & 968 & 182 & 1520 \\
\hline & Total & 485 & 1,394 & 1,786 & 1,316 & 3,952 \\
\hline
\end{tabular}


Table 2. Summary Statistics: CRSP Data. Summary statistics by pre-ranking risk, July 1971 through December 2011. We define the banking industry as the union of the banking SIC codes from Ken French's definition of 48 industries and the three-digit SIC 671, which includes bank holding companies. Pre-ranking beta is computed by regressing a minimum of 24 months and a maximum of 60 months of trailing holding period returns in excess of the riskless rate on the corresponding CRSP value-weighted market holding period returns (VWRETD, also in excess of the riskless rate). Pre-ranking root mean squared error uses the residuals from these regressions. In the first two panels, the sample is divided within each month into low (bottom 30\%), medium (middle 40\%), and high (top 30\%) portfolios according to pre-ranking beta. The last panel sorts by RMSE. Market capitalization is equal to price (PRC) times shares outstanding (SHROUT). Book-to-market ratio is the ratio of book equity to market capitalization. Book equity is computed as described in Ken French's data library. The sample includes firms for which we can compute a valid beta, with at least 24 monthly holding period return (RET) observations, a valid market capitalization, with a nonmissing price (PRC) and shares outstanding (SHROUT) observation, and at least one holding period return following a valid beta.

\begin{tabular}{|c|c|c|c|c|c|c|}
\hline & \multicolumn{6}{|c|}{ Pre-Ranking Risk } \\
\hline & \multicolumn{3}{|c|}{ Bottom } & \multicolumn{2}{|l|}{ Middle } & \multirow{2}{*}{$\begin{array}{l}\text { Top } \\
30 \%\end{array}$} \\
\hline & $\mathbf{N}$ & $30 \%$ & $\mathbf{N}$ & $40 \%$ & $\mathbf{N}$ & \\
\hline \multicolumn{7}{|l|}{ Panel A. Means, Pre-Ranking Beta Sorts } \\
\hline Pre-Ranking Beta & 82,082 & 0.18 & 109,456 & 0.68 & 80,493 & 1.37 \\
\hline Decile & 82,082 & 2.00 & 109,456 & 5.50 & 80,493 & 8.99 \\
\hline Pre-Ranking Root Mean Squared Error (\%) & 82,082 & 8.05 & 109,456 & 8.37 & 80,493 & 10.94 \\
\hline Decile & 82,082 & 4.69 & 109,456 & 5.15 & 80,493 & 6.69 \\
\hline Market Capitalization (\$M) & 82,082 & 210.6 & 109,456 & 702.8 & 80,493 & $3,012.0$ \\
\hline Book-to-Market Ratio & 54,356 & 1.39 & 86,643 & 1.87 & 66,955 & 3.63 \\
\hline Return from t-12 through t-2 (\%) & 81,312 & 12.62 & 109,075 & 14.00 & 80,135 & 14.06 \\
\hline \multicolumn{7}{|l|}{ Panel B. Medians, Pre-Ranking Beta Sorts } \\
\hline Pre-Ranking Beta & & 0.21 & & 0.67 & & 1.27 \\
\hline Decile & & 2.00 & & 5.00 & & 9.00 \\
\hline Pre-Ranking Root Mean Squared Error (\%) & & 6.89 & & 7.35 & & 9.43 \\
\hline Decile & & 4.00 & & 5.00 & & 7.00 \\
\hline Market Capitalization & & 47.3 & & 95.8 & & 196.1 \\
\hline Book-to-Market Ratio & & 0.76 & & 0.76 & & 0.76 \\
\hline Return from t-12 through t-2 (\%) & & 8.86 & & 11.11 & & 10.29 \\
\hline \multicolumn{7}{|l|}{ Panel C. Means, Pre-Ranking RMSE Sorts } \\
\hline Pre-Ranking Beta & 82,420 & 0.56 & 109,288 & 0.71 & 80,323 & 0.95 \\
\hline Decile & 82,420 & 4.52 & 109,288 & 5.45 & 80,323 & 6.50 \\
\hline Pre-Ranking Root Mean Squared Error (\%) & 82,420 & 5.39 & 109,288 & 7.94 & 80,323 & 14.26 \\
\hline Decile & 82,420 & 2.00 & 109,288 & 5.50 & 80,323 & 8.99 \\
\hline Market Capitalization (\$M) & 82,420 & $2,172.5$ & 109,288 & $1,141.1$ & 80,323 & 409.5 \\
\hline Book-to-Market Ratio & 66,126 & 1.77 & 84,061 & 2.23 & 57,767 & 3.04 \\
\hline Return from t-12 through t-2 (\%) & 82,048 & 13.52 & 108,730 & 14.00 & 79,744 & 13.14 \\
\hline
\end{tabular}


Table 3. Realized Portfolio Beta and Bank Capital. Portfolio betas by capital adequacy decile, March 1996 through February 2011. The sample is divided within each month into ten decile portfolios according to capital. Each portfolio total return in excess of the riskless rate is computed using either equal or value weights. The first two columns use the ratio of total equity capital (RCFD3210) divided by average total assets (RCFD3368). The second two columns use Tier 1 capital (RCFD8274) in place of total equity capital. The third two columns use total risk-based capital (RCFD3792) in place of total equity capital. The fourth and fifth pairs of columns use total riskweighted assets (RCFDa223) in place of average total assets. The sample runs from March 1996, the first date where RCFD8274 is available, through February 2011. It includes 74,105 firm-months for which we can compute capital ratios from the Federal Reserve Bank, a valid market capitalization, with a nonmissing price (PRC) and shares outstanding (SHROUT) observation, and at least one holding period return following a valid capital ratio.

\begin{tabular}{|c|c|c|c|c|c|c|c|c|c|c|}
\hline \multirow[t]{2}{*}{$\begin{array}{l}\text { Decile } \\
\text { Sorts } \\
\text { By: }\end{array}$} & \multicolumn{2}{|c|}{ Equity to Assets } & \multicolumn{2}{|c|}{$\begin{array}{c}\text { Tier } 1 \text { Capital to } \\
\text { Assets } \\
\end{array}$} & \multicolumn{2}{|c|}{$\begin{array}{c}\text { Risk-Based } \\
\text { Capital to Assets } \\
\end{array}$} & \multicolumn{2}{|c|}{$\begin{array}{c}\text { Tier } 1 \text { Capital to } \\
\text { Risk-Weighted } \\
\text { Assets } \\
\end{array}$} & \multicolumn{2}{|c|}{$\begin{array}{c}\text { Risk-Based Capital } \\
\text { to Risk-Weighted } \\
\text { Assets } \\
\end{array}$} \\
\hline & EW & VW & EW & VW & EW & VW & EW & VW & EW & VW \\
\hline \multicolumn{11}{|c|}{ Panel A. Capital Adequacy (\%), Decile Median and Value-Weighted Mean } \\
\hline 1 & 6.58 & 6.58 & 6.15 & 6.27 & 7.02 & 6.78 & 8.24 & 8.16 & 10.26 & 10.45 \\
\hline 2 & 7.54 & 7.60 & 6.84 & 6.85 & 7.81 & 8.05 & 9.30 & 9.30 & 10.79 & 10.91 \\
\hline 3 & 8.05 & 8.03 & 7.23 & 7.27 & 8.27 & 8.44 & 9.77 & 9.85 & 11.17 & 11.23 \\
\hline 4 & 8.46 & 8.66 & 7.55 & 7.55 & 8.62 & 8.74 & 10.17 & 10.30 & 11.54 & 11.55 \\
\hline 5 & 8.82 & 8.92 & 7.88 & 7.87 & 8.94 & 9.03 & 10.61 & 10.83 & 11.93 & 12.00 \\
\hline 6 & 9.19 & 9.25 & 8.21 & 8.24 & 9.27 & 9.39 & 11.11 & 11.29 & 12.41 & 12.38 \\
\hline 7 & 9.64 & 9.94 & 8.59 & 8.66 & 9.67 & 9.73 & 11.70 & 11.90 & 12.98 & 13.01 \\
\hline 8 & 10.17 & 10.74 & 9.09 & 9.05 & 10.16 & 10.19 & 12.51 & 12.60 & 13.77 & 13.70 \\
\hline 9 & 11.00 & 10.92 & 9.81 & 9.95 & 10.87 & 10.78 & 13.94 & 14.02 & 15.18 & 15.17 \\
\hline 10 & 13.24 & 15.26 & 11.45 & 14.33 & 12.51 & 13.74 & 17.26 & 18.36 & 18.45 & 19.82 \\
\hline $10-1$ & 6.66 & 8.68 & 5.29 & 8.06 & 5.48 & 6.96 & 9.02 & 10.20 & 8.20 & 9.37 \\
\hline \multicolumn{11}{|c|}{ Panel B. Realized Portfolio Beta, Equal and Value-Weighted Decile Portfolios } \\
\hline 1 & 0.80 & 1.20 & 0.86 & 1.35 & 0.78 & 0.97 & 0.93 & 1.24 & 0.76 & 0.80 \\
\hline 2 & 0.65 & 1.18 & 0.74 & 1.12 & 0.64 & 0.88 & 0.82 & 1.16 & 0.75 & 0.89 \\
\hline 3 & 0.60 & 0.78 & 0.68 & 0.95 & 0.65 & 1.04 & 0.67 & 1.29 & 0.71 & 1.00 \\
\hline 4 & 0.65 & 1.04 & 0.67 & 0.92 & 0.65 & 1.19 & 0.66 & 1.11 & 0.70 & 1.11 \\
\hline 5 & 0.70 & 1.11 & 0.66 & 1.05 & 0.64 & 1.12 & 0.63 & 0.96 & 0.67 & 1.06 \\
\hline 6 & 0.70 & 1.05 & 0.69 & 1.12 & 0.68 & 1.07 & 0.69 & 0.98 & 0.73 & 1.19 \\
\hline 7 & 0.66 & 1.26 & 0.60 & 1.00 & 0.63 & 1.16 & 0.61 & 0.76 & 0.64 & 1.14 \\
\hline 8 & 0.59 & 1.19 & 0.64 & 1.02 & 0.63 & 1.10 & 0.63 & 0.92 & 0.64 & 1.14 \\
\hline 9 & 0.66 & 1.03 & 0.54 & 0.81 & 0.71 & 1.23 & 0.50 & 1.08 & 0.55 & 1.03 \\
\hline 10 & 0.63 & 1.23 & 0.57 & 1.24 & 0.63 & 1.27 & 0.50 & 0.91 & 0.49 & 0.96 \\
\hline $10-1$ & -0.18 & 0.03 & -0.28 & -0.11 & -0.15 & 0.30 & -0.43 & -0.34 & -0.26 & 0.16 \\
\hline \multicolumn{11}{|c|}{ Panel C. T-Stats for Panel B } \\
\hline 10-1 & {$[-1.8]$} & [0.3] & {$[-2.8]$} & {$[-1.1]$} & {$[-1.6]$} & [3.3] & {$[-4.0]$} & {$[-3.6]$} & {$[-2.5]$} & [1.5] \\
\hline
\end{tabular}


Table 4. Bank Capital and Forward Systematic and Idiosyncratic Risk. Regressions of forward beta or idiosyncratic risk on measures of bank capital. The dependent variable in Panels A and B is the forward beta, computed by regressing a minimum of 24 months and a maximum of 60 months of trailing holding period returns in excess of the riskless rate on the corresponding CRSP value-weighted market holding period returns (VWRETD, also in excess of the riskless rate). The dependent variable in Panels $\mathrm{C}$ and $\mathrm{D}$ is the root mean squared residual from these regressions. Both are Winsorized at $1 \%$ and $99 \%$. The first two columns use the ratio of total equity capital (RCFD3210) divided by average total assets (RCFD3368) as the independent variable. The second two columns use Tier 1 capital (RCFD8274) in place of total equity capital. The third two columns use total risk-based capital (RCFD3792) in place of total equity capital. The fourth and fifth pairs of columns use total risk-weighted assets (RCFDa223) in place of average total assets. The sample runs from March 1996, the first date where RCFD8274 is available, through December 2010. The last forward beta that we can compute is in December 2010, using CRSP data through December 2012.

\begin{tabular}{|c|c|c|c|c|c|c|c|c|c|c|}
\hline & \multicolumn{2}{|c|}{ Equity to Assets } & \multicolumn{2}{|c|}{$\begin{array}{c}\text { Tier } 1 \text { Capital } \\
\text { to Assets }\end{array}$} & \multicolumn{2}{|c|}{$\begin{array}{l}\text { Risk-Based } \\
\text { Capital to } \\
\text { Assets }\end{array}$} & \multicolumn{2}{|c|}{$\begin{array}{c}\text { Tier } 1 \text { Capital } \\
\text { to Risk- } \\
\text { Weighted } \\
\text { Assets }\end{array}$} & \multicolumn{2}{|c|}{$\begin{array}{c}\text { Risk-Based } \\
\text { Capital to } \\
\text { Risk-Weighted } \\
\text { Assets } \\
\end{array}$} \\
\hline & Coef & {$[\mathrm{T}]$} & Coef & [T] & Coef & [T] & Coef & [T] & Coef & [T] \\
\hline \multicolumn{11}{|c|}{ Panel A: Fama-MacBeth, Dependent Variable is Forward Beta } \\
\hline Inverse Capital Ratio & 0.011 & {$[5.8]$} & 0.031 & {$[20.8]$} & 0.011 & [9.2] & 0.058 & {$[27.4]$} & 0.056 & [23.5] \\
\hline Intercept & 0.549 & [18.6 & 0.297 & [12.4] & 0.560 & [31.3] & 0.160 & [7.2] & 0.234 & [11.2] \\
\hline Observations & & 59,316 & & 59,316 & & 59,316 & & 59,316 & & 59,316 \\
\hline $\mathrm{T}$ & & 178 & & 178 & & 178 & & 178 & & 178 \\
\hline Average R-Squared & & 0.015 & & 0.032 & & 0.006 & & 0.072 & & 0.036 \\
\hline \multicolumn{11}{|c|}{ Panel B: Pooled with 2D Clustering, Dependent Variable is Forward Beta } \\
\hline Inverse Capital Ratio & -0.011 & {$[-1.5]$} & 0.019 & [2.9] & -0.003 & {$[-0.4]$} & 0.058 & {$[8.0]$} & 0.057 & [5.9] \\
\hline Intercept & 0.802 & [9.6] & 0.442 & [5.3] & 0.714 & [7.5] & 0.154 & [2.3] & 0.225 & [2.8] \\
\hline Observations & & 59,316 & & 59,316 & & 59,316 & & 59,316 & & 59,316 \\
\hline Average R-Squared & & 0.002 & & 0.007 & & 0.000 & & 0.045 & & 0.023 \\
\hline \multicolumn{11}{|c|}{ Panel C: Fama-MacBeth, Dependent Variable is Forward RMSE (\%) } \\
\hline Inverse Capital Ratio & 0.160 & [7.7] & 0.010 & {$[0.5]$} & 0.032 & [1.2] & 0.332 & {$[11.0]$} & 0.603 & [13.4] \\
\hline Intercept & 7.669 & [22.6] & 9.318 & [24.5] & 9.078 & [20.9] & 6.462 & [27.5] & 4.656 & [15.7] \\
\hline Observations & & 59,316 & & 59,316 & & 59,316 & & 59,316 & & 59,316 \\
\hline $\mathrm{T}$ & & 178 & & 178 & & 178 & & 178 & & 178 \\
\hline Average R-Squared & & 0.028 & & 0.013 & & 0.019 & & 0.024 & & 0.036 \\
\hline \multicolumn{11}{|c|}{ Panel D: Pooled with 2D Clustering, Dependent Variable is Forward RMSE (\%) } \\
\hline Inverse Capital Ratio & -0.059 & {$[-0.8]$} & -0.103 & {$[-1.6]$} & -0.091 & {$[-1.1]$} & 0.363 & {$[4.6]$} & 0.678 & [6.3] \\
\hline Intercept & 10.101 & [11.0] & 10.720 & [12.4] & 10.436 & [10.9] & 6.176 & [9.3] & 4.061 & [5.2] \\
\hline Observations & & 59,316 & & 59,316 & & 59,316 & & 59,316 & & 59,316 \\
\hline Average R-Squared & & 0.001 & & 0.002 & & 0.001 & & 0.017 & & 0.030 \\
\hline
\end{tabular}


Table 5. Returns and Beta: Fama-MacBeth Regressions. Regressions of excess returns on pre-ranking beta deciles. Pre-ranking beta, market capitalization, book-to-market ratio, past returns, and the sample are described in Table 2.

\begin{tabular}{|c|c|c|c|c|}
\hline \multirow[t]{2}{*}{$\begin{array}{l}\text { Dependent Variable: } \\
\text { Excess Return (Basis Points) }\end{array}$} & \multicolumn{2}{|c|}{ Univariate } & \multicolumn{2}{|c|}{ Multivariate } \\
\hline & Coefficient & [T] & Coefficient & [T] \\
\hline Pre-Ranking Beta Decile & -0.5 & {$[-0.19]$} & 0.8 & {$[0.33]$} \\
\hline Log (Market Capitalization (\$M)) & & & -2.1 & {$[-0.45]$} \\
\hline Book-to-Market Ratio Decile & & & 11.4 & {$[5.95]$} \\
\hline Return from $\mathrm{t}-12$ through $\mathrm{t}-2$ (\%) Decile & & & 15.3 & [6.72] \\
\hline Intercept & 63.9 & [3.98] & -65.4 & {$[-1.05]$} \\
\hline Observations & & 272,031 & & 207,267 \\
\hline $\mathrm{T}$ & & 486 & & 486 \\
\hline Average R-Squared & & 0.0203 & & 0.0676 \\
\hline
\end{tabular}


Table 6. Realized Returns and Risk: Beta Portfolios. Regressions of portfolio returns on market excess returns and the Fama-French factors, SMB and HML. Each portfolio total return in excess of the riskless rate is computed using either equal or value weights. The sample is divided within each month into low (bottom 30\%), medium (middle 40\%), and high (top 30\%) portfolios according to pre-ranking beta. Pre-ranking beta and the sample are described in Table 2.

Panel A. Equal Weighted

\begin{tabular}{|c|c|c|c|c|c|c|c|c|}
\hline \multirow[b]{2}{*}{ Basis Points } & \multicolumn{2}{|c|}{ Bottom 30\% } & \multicolumn{2}{|c|}{ Middle 40\% } & \multicolumn{2}{|c|}{ Тор 30\% } & \multicolumn{2}{|c|}{ Top - Bottom } \\
\hline & Coefficient & [T] & Coefficient & {$[\mathrm{T}]$} & Coefficient & [T] & Coefficient & {$[\mathrm{T}]$} \\
\hline \multicolumn{9}{|c|}{ Mean Excess Returns } \\
\hline & 59.1 & [3.42] & 65.0 & {$[2.90]$} & 58.2 & [1.93] & -0.9 & {$[-0.05]$} \\
\hline \multicolumn{9}{|c|}{ CAPM Regressions } \\
\hline Market & 0.56 & [18.91] & 0.81 & [23.51] & 1.14 & [26.15] & 0.59 & {$[17.67]$} \\
\hline Intercept & 33.6 & {$[2.55]$} & 28.0 & {$[1.82]$} & 5.9 & {$[0.30]$} & -27.7 & {$[-1.86]$} \\
\hline $\mathrm{T}$ & & 486 & & 486 & & 486 & & 486 \\
\hline R-Squared & & 0.425 & & 0.533 & & 0.586 & & 0.392 \\
\hline \multicolumn{9}{|c|}{ Fama-French 3-Factor Regressions } \\
\hline Market & 0.55 & [21.59] & 0.80 & [28.96] & 1.15 & {$[32.29]$} & 0.60 & {$[18.63]$} \\
\hline SMB & 0.38 & [10.46] & 0.47 & [11.74] & 0.52 & [10.24] & 0.14 & [3.08] \\
\hline HML & 0.46 & [12.04] & 0.65 & [15.50] & 0.89 & [16.48] & 0.43 & [8.71] \\
\hline Intercept & 9.1 & {$[0.82]$} & -5.6 & {$[-0.45]$} & -38.3 & {$[-2.44]$} & -47.4 & {$[-3.33]$} \\
\hline $\mathrm{T}$ & & 486 & & 486 & & 486 & & 486 \\
\hline R-Squared & & 0.602 & & 0.716 & & 0.743 & & 0.460 \\
\hline
\end{tabular}

Panel B. Value Weighted

\begin{tabular}{|c|c|c|c|c|c|c|c|c|}
\hline \multirow[b]{2}{*}{ Basis Points } & \multicolumn{2}{|c|}{ Bottom 30\% } & \multicolumn{2}{|c|}{ Middle $40 \%$} & \multicolumn{2}{|c|}{ Tор 30\% } & \multicolumn{2}{|c|}{ Top - Bottom } \\
\hline & Coefficient & [T] & Coefficient & {$[\mathrm{T}]$} & Coefficient & {$[\mathrm{T}]$} & Coefficient & {$[\mathbf{T}]$} \\
\hline \multicolumn{9}{|c|}{ Mean Excess Returns } \\
\hline & 52.2 & [2.37] & 56.1 & {$[2.31]$} & 36.4 & [1.21] & -15.8 & {$[-0.71]$} \\
\hline \multicolumn{9}{|c|}{ CAPM Regressions } \\
\hline Market & 0.71 & [19.17] & 0.95 & [28.87] & 1.27 & [35.73] & 0.55 & {$[12.93]$} \\
\hline Intercept & 19.6 & [1.17] & 12.4 & {$[0.84]$} & -21.6 & {$[-1.36]$} & -41.2 & {$[-2.14]$} \\
\hline $\mathrm{T}$ & & 486 & & 486 & & 486 & & 486 \\
\hline R-Squared & & 0.432 & & 0.633 & & 0.725 & & 0.257 \\
\hline \multicolumn{9}{|c|}{ Fama-French 3-Factor Regressions } \\
\hline Market & 0.72 & [19.78] & 1.00 & [31.46] & 1.32 & {$[38.74]$} & 0.60 & {$[13.90]$} \\
\hline SMB & 0.20 & [3.78] & -0.03 & {$[-0.58]$} & -0.13 & {$[-2.62]$} & -0.33 & {$[-5.24]$} \\
\hline HML & 0.46 & [8.33] & 0.59 & [12.35] & 0.69 & [13.41] & 0.23 & [3.57] \\
\hline Intercept & -1.9 & {$[-0.12]$} & -11.5 & {$[-0.83]$} & -47.9 & {$[-3.18]$} & -46.0 & {$[-2.41]$} \\
\hline $\mathrm{T}$ & & 486 & & 486 & & 486 & & 486 \\
\hline R-Squared & & 0.492 & & 0.684 & & 0.762 & & 0.291 \\
\hline
\end{tabular}


Table 7. Realized Returns and Risk: Idiosyncratic Risk Portfolios. Regressions of portfolio returns on market excess returns and the Fama-French factors, SMB and HML. Each portfolio total return in excess of the riskless rate is computed using either equal or value weights. The sample is divided within each month into low (bottom $30 \%$ ), medium (middle 40\%), and high (top 30\%) portfolios according to pre-ranking root mean squared error. Pre-ranking root mean squared error and the sample are described in Table 2.

Panel A. Equal Weighted

\begin{tabular}{|c|c|c|c|c|c|c|c|c|}
\hline \multirow[b]{2}{*}{ Basis Points } & \multicolumn{2}{|c|}{ Bottom 30\% } & \multicolumn{2}{|c|}{ Middle 40\% } & \multicolumn{2}{|c|}{ Тор 30\% } & \multicolumn{2}{|c|}{ Top - Bottom } \\
\hline & Coefficient & [T] & Coefficient & {$[\mathrm{T}]$} & Coefficient & [T] & Coefficient & {$[\mathrm{T}]$} \\
\hline \multicolumn{9}{|c|}{ Mean Excess Returns } \\
\hline & 70.8 & [4.23] & 67.6 & [3.05] & 42.6 & [1.35] & -28.1 & {$[-1.34]$} \\
\hline \multicolumn{9}{|c|}{ CAPM Regressions } \\
\hline Market & 0.64 & [27.31] & 0.82 & [25.24] & 1.03 & {$[19.50]$} & 0.39 & {$[9.02]$} \\
\hline Intercept & 41.3 & {$[3.92]$} & 29.9 & {$[2.04]$} & -4.8 & {$[-0.20]$} & -46.1 & {$[-2.36]$} \\
\hline $\mathrm{T}$ & & 486 & & 486 & & 486 & & 486 \\
\hline R-Squared & & 0.607 & & 0.568 & & 0.440 & & 0.144 \\
\hline \multicolumn{9}{|c|}{ Fama-French 3-Factor Regressions } \\
\hline Market & 0.65 & [29.55] & 0.82 & [31.52] & 1.02 & {$[24.28]$} & 0.38 & {$[9.95]$} \\
\hline SMB & 0.17 & [5.35] & 0.43 & [11.32] & 0.80 & [13.23] & 0.63 & [11.61] \\
\hline HML & 0.42 & [12.70] & 0.67 & [16.92] & 0.91 & [14.24] & 0.49 & {$[8.50]$} \\
\hline Intercept & 22.0 & [2.28] & -3.8 & {$[-0.33]$} & -54.3 & {$[-2.92]$} & -76.3 & {$[-4.56]$} \\
\hline $\mathrm{T}$ & & 486 & & 486 & & 486 & & 486 \\
\hline R-Squared & & 0.682 & & 0.741 & & 0.670 & & 0.393 \\
\hline
\end{tabular}

Panel B. Value Weighted

\begin{tabular}{|c|c|c|c|c|c|c|c|c|}
\hline \multirow[b]{2}{*}{ Basis Points } & \multicolumn{2}{|c|}{ Bottom 30\% } & \multicolumn{2}{|c|}{ Middle 40\% } & \multicolumn{2}{|c|}{ Тор 30\% } & \multicolumn{2}{|c|}{ Top - Bottom } \\
\hline & Coefficient & [T] & Coefficient & {$[\mathrm{T}]$} & Coefficient & {$[\mathrm{T}]$} & Coefficient & [T] \\
\hline \multicolumn{9}{|c|}{ Mean Excess Returns } \\
\hline & 55.7 & {$[2.26]$} & 43.8 & {$[1.56]$} & 49.4 & [1.42] & -6.3 & {$[-0.29]$} \\
\hline \multicolumn{9}{|c|}{ CAPM Regressions } \\
\hline Market & 1.02 & [34.23] & 1.16 & [33.62] & 1.32 & [26.40] & 0.30 & [6.30] \\
\hline Intercept & 8.9 & {$[0.66]$} & -9.2 & {$[-0.60]$} & -11.0 & {$[-0.49]$} & -19.8 & {$[-0.94]$} \\
\hline $\mathrm{T}$ & & 486 & & 486 & & 486 & & 486 \\
\hline R-Squared & & 0.708 & & 0.700 & & 0.590 & & 0.076 \\
\hline \multicolumn{9}{|c|}{ Fama-French 3-Factor Regressions } \\
\hline Market & 1.08 & [37.65] & 1.21 & [38.06] & 1.34 & [29.36] & 0.26 & [6.00] \\
\hline SMB & -0.27 & {$[-6.60]$} & -0.03 & {$[-0.69]$} & 0.34 & {$[5.20]$} & 0.62 & [9.86] \\
\hline HML & 0.51 & [11.67] & 0.71 & [14.72] & 0.87 & [12.57] & 0.36 & [5.52] \\
\hline Intercept & -7.9 & {$[-0.62]$} & -38.1 & {$[-2.71]$} & -51.7 & {$[-2.56]$} & -43.9 & {$[-2.29]$} \\
\hline $\mathrm{T}$ & & 486 & & 486 & & 486 & & 486 \\
\hline R-Squared & & 0.747 & & 0.760 & & 0.679 & & 0.263 \\
\hline
\end{tabular}


Table 8. Realized Returns and Risk: Robustness. Regressions of portfolio returns on market excess returns and the Fama-French factors, SMB and HML. Each portfolio total return in excess of the riskless rate is computed using either equal or value weights. The sample is divided within each month into low (bottom 30\%), medium (middle 40\%), and high (top 30\%) portfolios according to pre-ranking beta or pre-ranking root mean squared error. Pre-ranking beta and root mean squared error and the sample are described in Table 2. All portfolios are value-weighted. The first four pairs of columns use only bank stocks, while the last two pairs of columns use the full CRSP sample.

\begin{tabular}{|c|c|c|c|c|c|c|c|c|c|c|c|c|}
\hline \multirow[b]{2}{*}{ Basis Points } & \multicolumn{2}{|c|}{$\begin{array}{c}\text { Beta: Top-Bottom, } \\
\text { Bank Stocks, July } \\
\text { 1971-December } 2011\end{array}$} & \multicolumn{2}{|c|}{$\begin{array}{c}\text { Beta: Top-Bottom, } \\
\text { Bank Stocks, January } \\
\text { 1931-December } 2011 \\
\end{array}$} & \multicolumn{2}{|c|}{$\begin{array}{c}\text { Idiosyncratic Risk: } \\
\text { Top-Bottom, Bank } \\
\text { Stocks, July 1971- } \\
\text { December } 2011 \\
\end{array}$} & \multicolumn{2}{|c|}{$\begin{array}{l}\text { Idiosyncratic Risk: } \\
\text { Top-Bottom, Bank } \\
\text { Stocks, January } \\
\text { 1931-December } 2011 \\
\end{array}$} & \multicolumn{2}{|c|}{$\begin{array}{c}\text { Beta: Top-Bottom, All } \\
\text { Stocks, July 1971- } \\
\text { December } 2011 \\
\end{array}$} & \multicolumn{2}{|c|}{$\begin{array}{c}\text { Beta: Top-Bottom, } \\
\text { All Stocks, } \\
\text { January 1931- } \\
\text { December 2011 } \\
\end{array}$} \\
\hline & Coefficient & {$[\mathrm{T}]$} & Coefficient & [T] & Coefficient & [T] & Coefficient & [T] & Coefficient & [T] & Coefficient & [T] \\
\hline \multicolumn{13}{|c|}{ CAPM Regressions } \\
\hline Market & 0.55 & [12.93] & 0.74 & [18.59] & 0.30 & {$[6.30]$} & 0.50 & {$[9.47]$} & 0.71 & [19.47] & 0.80 & [37.92] \\
\hline Intercept & -41.2 & {$[-2.14]$} & -44.6 & {$[-2.10]$} & -19.8 & {$[-0.94]$} & -24.8 & {$[-0.87]$} & -37.7 & {$[-2.32]$} & -35.3 & {$[-3.14]$} \\
\hline $\mathrm{T}$ & & 486 & & 972 & & 486 & & 972 & & 486 & & 972 \\
\hline R-Squared & & 0.257 & & 0.263 & & 0.076 & & 0.085 & & 0.439 & & 0.597 \\
\hline \multicolumn{13}{|c|}{ Fama-French 3-Factor Regressions } \\
\hline Market & 0.60 & [13.90] & 0.64 & [15.75] & 0.26 & [6.00] & 0.18 & [3.58] & 0.63 & [18.66] & 0.70 & [34.42] \\
\hline SMB & -0.33 & {$[-5.24]$} & -0.13 & {$[-2.05]$} & 0.62 & [9.86] & 1.04 & [13.05] & 0.25 & [5.19] & 0.35 & [10.69] \\
\hline HML & 0.23 & [3.57] & 0.56 & [9.73] & 0.36 & [5.52] & 0.61 & {$[8.51]$} & -0.17 & {$[-3.23]$} & 0.15 & [5.30] \\
\hline Intercept & -46.0 & {$[-2.41]$} & -58.3 & {$[-2.84]$} & -43.9 & {$[-2.29]$} & -61.2 & {$[-2.41]$} & -32.3 & {$[-2.16]$} & -46.1 & {$[-4.49]$} \\
\hline $\mathrm{T}$ & & 486 & & 972 & & 486 & & 972 & & 486 & & 972 \\
\hline R-Squared & & 0.291 & & 0.320 & & 0.263 & & 0.273 & & 0.540 & & 0.671 \\
\hline
\end{tabular}


Table 9. Theoretical Determinants of Changes in WACC. This table summarizes how the weighted average cost of capital depends on assumptions regarding the efficiency of the debt market, its integration with the equity market, and the existence of a government subsidy.

\begin{tabular}{|c|c|c|c|c|}
\hline \multicolumn{4}{|c|}{ Bank Debt } & \multirow[b]{2}{*}{$\triangle W A C C$} \\
\hline Risk & Pricing & $\begin{array}{l}\text { Integrated } \\
\text { Markets }\end{array}$ & Government Subsidy & \\
\hline Risky & $\begin{array}{l}\text { Correctly } \\
\text { Priced }\end{array}$ & No & No & $\gamma\left(e-e^{*}+A\left(e, e^{*}\right)\right)$ \\
\hline Risk Free & $\begin{array}{l}\text { Correctly } \\
\text { Priced }\end{array}$ & No & No & $\gamma\left(e-e^{*}\right)$ \\
\hline Risky & $\begin{array}{l}\text { Low Risk } \\
\text { Anomaly }\end{array}$ & No & No & $\left(e-e^{*}\right)\left(\gamma-\bar{\beta}_{d} \gamma_{d}\right)+A\left(e, e^{*}\right)\left(\gamma-\gamma_{d}\right)$ \\
\hline Risky & $\begin{array}{l}\text { Low Risk } \\
\text { Anomaly } \\
\gamma=\gamma_{d}\end{array}$ & No & No & $\gamma\left(e-e^{*}\right)\left(1-\bar{\beta}_{d}\right)$ \\
\hline $\begin{array}{l}\text { Risky or } \\
\text { Risk Free }\end{array}$ & $\begin{array}{l}\text { Low Risk } \\
\text { Anomaly } \\
\gamma=\gamma_{d}\end{array}$ & $\begin{array}{l}\text { Yes } \\
\bar{\beta}_{d}=1\end{array}$ & No & 0 \\
\hline Risky & $\begin{array}{l}\text { Correctly } \\
\text { Priced }\end{array}$ & No & Yes & $\gamma\left(e-e^{*}\right)+A\left(e, e^{*}\right)\left(\gamma+r_{p}\right)$ \\
\hline
\end{tabular}


Appendix: Sample Bank Data. Example beta, RMSE, and Tier 1 capital ratio for select large and small capitalization banks as of December 2011. The first panel lists banks with greater than $\$ 5$ billion in market capitalization. The second panel lists banks with market capitalization between $\$ 75$ and $\$ 125$ million. Pre-ranking beta is computed by regressing a minimum of 24 months and a maximum of 60 months of trailing holding period returns in excess of the riskless rate on the corresponding CRSP value-weighted market holding period returns (VWRETD, also in excess of the riskless rate). Pre-ranking root mean squared error uses the residuals from these regressions. The first measure of capital adequacy is the ratio of total equity capital (RCFD3210) divided by average total assets (RCFD3368). The second replaces Tier 1 capital (RCFD8274) in place of total equity capital and uses total risk-weighted assets (RCFDa223) in place of average total assets. The third uses total risk-based capital (RCFD3792) in place of total equity capital.

\begin{tabular}{|c|c|c|c|c|c|c|}
\hline \multirow[b]{2}{*}{ Bank Name } & \multirow[b]{2}{*}{$\begin{array}{r}\text { Market } \\
\text { Cap } \\
\end{array}$} & \multicolumn{2}{|r|}{ Risk } & \multicolumn{3}{|c|}{ Capital Adequacy (\%) } \\
\hline & & Beta & $\begin{array}{r}\text { RMSE } \\
(\%) \\
\end{array}$ & $\begin{array}{r}\text { Equity } \\
\text { to } \\
\text { Assets } \\
\end{array}$ & $\begin{array}{r}\text { Tier } 1 \\
\text { Capital } \\
\text { to Risk- } \\
\text { Weighted } \\
\text { Assets } \\
\end{array}$ & $\begin{array}{r}\text { Risk- } \\
\text { Based } \\
\text { Capital } \\
\text { to Risk- } \\
\text { Weighted } \\
\text { Assets } \\
\end{array}$ \\
\hline \multicolumn{7}{|c|}{ Panel A. Large Capitalization Banks, Over \$5 Billion } \\
\hline CITIGROUP INC & 122,000 & 2.42 & 14.52 & 11.20 & 15.09 & 16.91 \\
\hline FIFTH THIRD BANCORP & 9,516 & 2.13 & 15.79 & 14.34 & 13.18 & 15.17 \\
\hline BANK OF AMERICA CORP & 110,400 & 2.01 & 14.26 & 11.40 & 11.54 & 14.73 \\
\hline AMERICAN EXPRESS CO & 52,027 & 1.91 & 11.00 & 19.22 & 18.26 & 19.53 \\
\hline CAPITAL ONE FINANCIAL CORP & 17,011 & 1.65 & 11.73 & 15.29 & 11.94 & 16.31 \\
\hline STATE STREET CORP & 21,687 & 1.31 & 8.70 & 10.80 & 18.14 & 19.99 \\
\hline WELLS FARGO \& CO NEW & 142,800 & 1.28 & 10.37 & 11.20 & 10.40 & 13.36 \\
\hline GOLDMAN SACHS GROUP INC & 79,825 & 1.24 & 8.46 & 19.22 & 18.87 & 23.94 \\
\hline SUNTRUST BANKS INC & 11,679 & 1.19 & 11.79 & 11.94 & 10.05 & 12.58 \\
\hline P N C FINANCIAL SERVICES GRP INC & 28,314 & 1.14 & 8.82 & 15.41 & 12.18 & 15.49 \\
\hline MORGAN STANLEY DEAN WITTER \& CO & 37,005 & 1.14 & 12.26 & 12.17 & 16.70 & 19.49 \\
\hline JPMORGAN CHASE \& CO & 146,200 & 1.08 & 8.06 & 8.40 & 9.71 & 13.59 \\
\hline REGIONS FINANCIAL CORP NEW & 6,758 & 1.01 & 13.27 & 11.92 & 11.68 & 14.93 \\
\hline COMERICA INC & 6,440 & 0.99 & 8.03 & 11.04 & 10.27 & 14.29 \\
\hline U S BANCORP DEL & 45,617 & 0.94 & 7.66 & 10.34 & 9.30 & 12.72 \\
\hline B B \& T CORP & 16,095 & 0.87 & 10.79 & 11.23 & 13.02 & 15.48 \\
\hline NORTHERN TRUST CORP & 12,182 & 0.76 & 6.22 & 9.14 & 13.12 & 15.72 \\
\hline M \& T BANK CORP & 9,187 & 0.69 & 8.62 & 13.24 & 8.82 & 12.43 \\
\hline NEW YORK COMMUNITY BANCORP INC & 7,318 & 0.68 & 6.57 & 14.40 & 13.51 & 14.18 \\
\hline BANK OF NEW YORK MELLON CORP & 33,480 & 0.61 & 6.36 & 9.68 & 12.14 & 15.76 \\
\hline KEYCORP NEW & 6,630 & 0.53 & 11.16 & 10.54 & 12.41 & 16.52 \\
\hline
\end{tabular}




\begin{tabular}{|c|c|c|c|c|c|c|}
\hline \multirow[b]{2}{*}{ Bank Name } & \multirow[b]{2}{*}{$\begin{array}{r}\text { Market } \\
\text { Cap } \\
\end{array}$} & \multicolumn{2}{|r|}{ Risk } & \multicolumn{3}{|c|}{ Capital Adequacy (\%) } \\
\hline & & Beta & $\begin{array}{r}\text { RMSE } \\
(\%) \\
\end{array}$ & $\begin{array}{r}\text { Equity } \\
\text { to } \\
\text { Assets } \\
\end{array}$ & $\begin{array}{r}\text { Tier } 1 \\
\text { Capital } \\
\text { to Risk- } \\
\text { Weighted } \\
\text { Assets } \\
\end{array}$ & $\begin{array}{r}\text { Risk- } \\
\text { Based } \\
\text { Capital } \\
\text { to Risk- } \\
\text { Weighted } \\
\text { Assets } \\
\end{array}$ \\
\hline \multicolumn{7}{|c|}{ Panel B. Small Capitalization Banks, \$75 to \$125 Million } \\
\hline HERITAGE COMMERCE CORP & 97 & 1.54 & 15.61 & 13.06 & 16.83 & 18.10 \\
\hline FIRST BANCORP P R & 77 & 1.05 & 19.07 & 7.63 & 10.28 & 11.57 \\
\hline NORTHRIM BANCORP INC & 121 & 1.02 & 7.68 & 11.94 & 13.11 & 14.36 \\
\hline HERITAGE OAKS BANCORP & 83 & 1.01 & 10.57 & 12.70 & 13.47 & 14.75 \\
\hline HORIZON BANCORP IND & 84 & 0.90 & 8.40 & 9.40 & 12.70 & 13.95 \\
\hline ENCORE BANCSHRES INC & 108 & 0.79 & 17.11 & 10.33 & 11.78 & 13.04 \\
\hline SOUTHERN NATIONAL BANCORP VA INC & 85 & 0.76 & 9.86 & 15.82 & 19.74 & 20.99 \\
\hline MIDDLEBURG FINANCIAL CORP & 97 & 0.70 & 7.74 & 8.40 & 12.28 & 13.54 \\
\hline MIDWESTONE FINANCIAL GRP INC NEW & 124 & 0.68 & 11.79 & 9.61 & 11.96 & 13.21 \\
\hline ENTERPRISE BANCORP INC & 106 & 0.62 & 6.77 & 9.04 & 10.11 & 11.42 \\
\hline BAR HARBOR BANKSHARES & 104 & 0.62 & 5.25 & 9.38 & 13.72 & 15.56 \\
\hline N B \& T FINANCIAL GROUP INC & 78 & 0.60 & 5.28 & 10.30 & 15.44 & 16.31 \\
\hline MONROE BANCORP & 76 & 0.58 & 20.92 & 8.28 & 12.44 & 13.71 \\
\hline PORTER BANCORP INC & 121 & 0.56 & 9.05 & 11.30 & 12.79 & 14.72 \\
\hline B N C BANCORP & 80 & 0.53 & 7.53 & 8.34 & 11.19 & 13.01 \\
\hline PREFERRED BANK LOS ANGELES & 105 & 0.43 & 15.39 & 10.69 & 13.75 & 15.02 \\
\hline OHIO VALLEY BANC CORP & 78 & 0.38 & 7.62 & 8.71 & 12.16 & 13.41 \\
\hline CHICOPEE BANCORP INC & 76 & 0.32 & 3.27 & 13.35 & 16.14 & 17.11 \\
\hline WILBER CORP & 100 & 0.28 & 11.38 & 8.29 & 13.22 & 14.48 \\
\hline B C B BANCORP INC & 88 & 0.26 & 4.98 & 9.16 & 14.95 & 15.89 \\
\hline NORWOOD FINANCIAL CORP & 78 & 0.18 & 5.26 & 12.35 & 17.94 & 19.23 \\
\hline CITIZENS HOLDING CO & 87 & 0.17 & 8.90 & 8.96 & 14.82 & 16.07 \\
\hline CENTURY BANCORP INC & 85 & 0.15 & 8.36 & 6.23 & 12.43 & 13.61 \\
\hline UNION BANKSHARES INC & 80 & 0.15 & 4.25 & 9.21 & 13.90 & 15.10 \\
\hline HINGHAM INSTITUTION FOR SVGS MA & 89 & 0.04 & 4.72 & 7.20 & 11.61 & 12.72 \\
\hline
\end{tabular}

